\title{
Economic growth and real exchange rate misalignments in the European Union
}

\author{
JUDIT KREKÓ ${ }^{1,2 *}$ (10) and GÁBOR OBLATH ${ }^{1}$
}

\author{
${ }^{1}$ Institute of Economics, Centre for Economic and Regional Studies, Tóth Kálmán u. 4, H-1097, \\ Budapest, Hungary \\ ${ }^{2}$ Central European University, Budapest, Hungary
}

Received: April 23, 2019 • Revised manuscript received: September 05, 2019 • Accepted: October 10, 2019

(c) 2020 The Author(s)

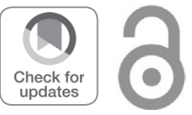

\begin{abstract}
We investigate the relationship between economic growth and real exchange rate (RER) misalignments within the European Union (EU) during the period of 1995-2016. In addition to the relative price level of GDP, we quantify an alternative indicator for the RER: the internal relative price of services to goods. We interpret RER misalignments as deviations from the levels consistent with the levels of economic development among the EU countries. Using pooled OLS and dynamic panel techniques, we find that within the EU over- (under-) valuations are associated with lower (higher) growth. This is mainly due to developments in the countries operating under the fixed exchange rate regimes. Our results indicate that the level of development does not influence the strength of the growth-misalignment relationship within the EU. Regarding the price level of GDP, we find that the positive relationship between undervaluation and growth diminishes with the degree of undervaluation. We find that overvaluation has a statistically significant negative effect on export market shares and private investments, indicating that both the competitiveness and the investment channels play a role in the relationship between growth and RER misalignments. As an extension, we show that the effects of "wage misalignments" from levels consistent with productivity are also negatively related to economic growth. The policy implications of the analysis point to the importance of a growth strategy avoiding overvaluation on the one hand, and to the futility of aiming at excessive undervaluation, on the other.
\end{abstract}

\section{KEYWORDS}

real economic and price level convergence, internal relative prices, exchange rate misalignment

\footnotetext{
*Corresponding author. E-mail: kreko.judit@krtk.mta.hu
} 


\section{JEL CLASSIFICATION INDICES}

E01, F45, 040, 047, 052, P22, P27

\section{INTRODUCTION ${ }^{1}$}

We start from the statistical observation that there is a very close spatial (cross-county) association between relative real incomes, comparative price levels and price structures within the European Union (EU) (e.g., Podkaminer 2010; Berka - Devereux 2013). ${ }^{2}$ Higher (lower) levels of real incomes tend to be accompanied by higher (lower) general price levels, as well as higher (lower) relative prices of services to goods. We shall refer to the comparative general price level the ratio of the purchasing power parity (PPP) of GDP to the nominal exchange rate - as the overall real exchange rate (RER). The ratio of the comparative price level of services to goods, in turn, is considered as an indicator of the internal RER.

As attested by the subsequent rounds of the Penn World Tables (PWT), the positive correlation between real incomes and price levels is a global phenomenon (Feenstra et al. 2015), but it holds much more closely within the EU. This relationship, however, does not generally hold at each point in time, or in the short-to-medium run for individual countries. Our study aims to investigate the implications of such "disconnects" between levels (structures) of relative prices and relative real incomes. We shall refer to these disconnects as misalignments of the overall/ internal RER from relative real incomes. Our primary interest lies in the relationship between misalignments and economic growth.

The concept of misalignment presumes that there is a "non-misaligned" (benchmark or "neutral") level/structure of prices corresponding to the actual state of economic development of a particular country. The basic notion underlying our study is that within a group of countries consisting of members at considerably different levels of economic development, but closely integrated by trade, capital and labour flows - such is the EU - the overall pattern reflecting the relationship between relative prices and incomes for the group as a whole offers guidance for judging RER-misalignments in individual members of the group. This practically means that in this study the regression line (more precisely: regressions based on alternative specifications) expressing the relationship between prices and incomes for the EU as a whole is taken as the benchmark for the empirical interpretation of misalignments in the member-states. Positive/ negative deviations from the benchmark are interpreted as indications of over/undervaluation with respect to the specified benchmark.

We first quantify indicators of misalignment and continue by investigating the relationship between misalignment and growth in per capita GDP. Similarly to other works on the topic (e.g.,

\footnotetext{
${ }^{1}$ The article draws on an extensive study by the authors (Krekó - Oblath 2018), which addresses several issues belonging to our topic, but not discussed in this article, in particular, convergence in income and price levels within the EU. Due to limitations of space, Section 5 of the article, Table 1, most of the figures, as well as the Appendix are omitted from the printed version, but they are accessible online as "Complementary text, figures, tables and appendices to the article" at https://www.mtakti.hu/wp-content/uploads/2020/06/Complementary.docx.

${ }^{2}$ The term "comparative" refers to the fact that spatial price levels/structures can be interpreted only in comparison to a reference country or a group of countries, e.g., the average of the EU.
} 
Aguirre - Calderon 2005; Gala 2008; Rodrik 2008; Habib et al. 2017), we complement standard growth equations with indicators of misalignment. While following the two-step procedure of earlier studies, our article intends to contribute to the literature on the relationship between RER-misalignments and economic growth in several respects.

First, and most importantly, the literature on this topic has mainly addressed the experiences of developing countries, or a very broad set of countries; just a few studies dealt specifically with the EU. Our work, in turn, focuses on the experiences of the present memberstates of the EU, consisting of countries at medium and high levels of income. Their economies are deeply integrated, and most are very open, implying that the RER has an important economic role.

Second, studies related to our topic generally rely on the overall RER (the comparative price level of GDP) for quantifying misalignments. We draw on the internal RER (the relative price of services to goods) as well, since the indicators of misalignment based on internal relative prices may capture the effect of domestic price distortions - not necessarily reflected by the indicators of external RER-misalignment. The internal relative price of services to goods, in contrast to the relative price of GDP is not directly influenced by changes in the nominal exchange rate. Hence, it can be especially relevant among the countries of the Eurozone. A further reason for addressing the relative price of services to goods is that it can be considered as a proxy for the relative price of non-tradables to tradables, which is essential in the supply-side explanations of the association between RER and the level of economic development. Moreover, the demand-side explanations of this association also stress the role of the relative price of services to goods.

Third, we address several aspects of country level heterogeneity in our sample. In particular, we intend to clarify, whether the level of development, approximated by belonging to the Central and East-European (CEEU) member-states, or maintaining a fixed exchange rate regime makes a difference in the relationship between misalignment and growth. We also investigate asymmetries (over-vs. undervaluation) and nonlinearities in the growthmisalignment relationship.

Fourth, we amend earlier endeavours to identify the channels through which RER misalignments may hurt or assist economic growth. Besides investments, already addressed in the previous studies (e.g., Razmi et al. 2012), we investigate the relationship between misalignments and alternative indicators of external trade performance. Since the majority of the EU-countries is very open, the "competitiveness-channel" is an important link between misalignments and economic growth.

Fifth, beyond results based on the estimations of RER-misalignments, we also consider the estimates relying on "wage-misalignments", as interpreted by the discrepancies between labour costs and productivity.

As compared to the results of the related literature, covering a larger sample of countries, in our sample including the EU27, the long term coefficient between the GDP price level and relative indicators of development, as well as the explanatory power of economic development in the price level of GDP and internal relative prices can be regarded as high. The relationship between relative GDP variables and relative internal prices is comparably strong, with the slope being less steep.

Our results indicate that the contemporaneous RER misalignment is associated with economic growth: a $10 \%$ over/undervaluation is accompanied by $0.1-0.6$ percentage point lower/ 
higher rate of growth across different specifications. The magnitude is similar for two RER indicators: the price level of GDP and the internal relative price. This effect is substantial, considering the fact that the mean annual growth rate of per capita GDP was $2.3 \%$ in the EU27 over the period covered by our analysis. However, the statistical significance of the results is sensitive to the specification and the composition of the sample. A robust finding of the study is that the relationship between growth and misalignment, both in the GDP price level and in internal relative prices, is attributable mostly to the countries operating under the fixed exchange rate regimes, i.e., to the Eurozone countries and the CEEU countries with pegged exchange rates. Regarding the price level of GDP, we find that the positive relationship between undervaluation and growth diminishes with the degree of undervaluation. We find that an increase in the misalignment - that is, moving towards overvaluation - has negative effect on both export market shares and the ratio of private gross fixed capital formation to GDP, indicating that both the competitiveness and the investment channel have an important role in connecting the effects of RER-misalignments with economic growth. We find that both relative price of GDP and the internal relative price play a role in the propagation mechanism.

An important finding is that in majority of the specifications, the internal relative price exhibits similar effect as the relative price of GDP. This result points to the robustness of our results to the alternative indicators. As the internal relative price reflects structural differences in prices and is only indirectly influenced by the nominal exchange rate, our results indicate that the RER changes might play an important role also without nominal exchange rate fluctuations.

The rest of the paper is structured as follows. In the next section, we define the key concepts of the study, review the related literature and present stylised facts related to our analyses. In Section 3, we estimate the alternative measures of RER-misalignment. Section 4 presents the results of our estimations regarding the relationship between economic growth and RER-misalignments. Section 5 (online) addresses issues related to the misalignments of wages. In Section 6 , we draw conclusions and indicate further lines of research. (Section 5, Table 1, most of the figures, as well as the Appendix can be accessed online at: https://www.mtakti.hu/wp-content/ uploads/2020/06/Complementary.docx.).

\section{KEY CONCEPTS, BACKGROUND AND STYLIZED FACTS}

\subsection{Concepts}

Three statistical concepts, matching three economic concepts, are central for our further analyses. The first is the cross-country (or spatial) comparative price level index of GDP, which we regard as an indicator of the overall RER level. The second is the spatial volume index of GDP per capita (or per labour input) - generally considered to be the indicator of the level of real income (or labour productivity). The third is the ratio of the spatial price level index of services to goods; we consider it as an indicator of the internal RER. In our empirical analyses we rely on the Eurostat PPP-database (containing PPPs calculated from the expenditure side of GDP) for quantifying these indicators.

(i) A cross-country price level index can be interpreted analogously to a price index measuring the change in price levels over time. The difference is that an ordinary price index, such as the CPI, reflects the change in prices between two points in time, while a spatial price index expresses the difference in price levels between countries at a point in time. A price level (PL) index is 
always measured relative to a reference country, or a group of countries (our choice is the latter: the average of the EU15). It is defined as the ratio of a purchasing power parity (PPP) to the nominal exchange rate (E) with respect to the reference group, i.e., $P L=P P P / E .^{3}$

It should be stressed that PPPs (and, by implication, price level indices) for different expenditure categories of GDP are likely to differ for individual countries, implying that there is no such thing as "the" PPP of a currency. Therefore, it is essential to indicate: for which a particular category of PPP (PL index) applies. Our analyses involve three major expenditure categories: GDP, total goods and total services, whose respective price level indices in country $i$ relative to the EU15 are denoted by $P L g d p^{i}, P L g^{i}$ and $P L s^{i}$.

Our overall price level index is based on the PPP for GDP:

$$
P L g d p^{i}=P P P g d p^{i} / E, \quad \text { where PPPgdp } p^{i}=P g d p^{i} / P g d p^{E U 15} .
$$

$P L g d p^{i}$ shows how much higher/lower the general price level of a country $i$ is relative to the EU15-average. In the following, we refer to PLgdp as the overall RER. Note that in the analyses of exchange rate developments, usually the inverse of our indicator (the ratio of the nominal exchange rate index to a relative price or cost index) is considered to reflect changes in RERs. According to our definition, an increase in the RER indicates appreciation, while a decrease indicates depreciation.

(ii) Spatial volume indices are obtained by dividing the nominal value index of a particular category (expressed in euro) by the PL of the respective category. The volume level index we rely on is that of per capita GDP $\left(V L C g d p^{i}\right)$ relative to the EU15. This indicator reflects the relative level of development (or relative real income) of a country, and it is also referred to as "real" per capita GDP in international comparisons. If GDP per labour input (persons employed or hours worked) is considered, an indicator of the relative level of labour productivity is obtained.

(iii) We define the internal relative price of two aggregates (components of GDP) as the ratio of their price level indices. For the purposes of our study, the most important internal relative price is that of services to goods, defined as $R P s g^{i}=P L s / P L g^{i}$. We consider this ratio as a measure of the internal RER. Similarly to the overall RER, its increase (decrease) involves the appreciation (depreciation) of the RER. It can be considered either as a proxy of the relative price of non-tradables to tradables, or as an indicator on its own right. ${ }^{4}$

\footnotetext{
${ }^{3}$ The PPP reflects the purchasing power of the domestic currency relative to a reference region. Our empirical work relies on the PPP database of the Eurostat, which expresses the purchasing power of currencies as compared to an artificial currency unit, called purchasing power standard (PPS). The PPS is defined so that 1 PPS has the same purchasing power as 1 euro with respect to an average of the EU member-states. In other words, the PPS shows the cost of a basket in country $i$, which costs 1 euro in the average of (a group of) the EU countries. Since the time series for certain items, in particular, goods and services, expressed in PPS-EU28 are relatively short, our analyses rely on data measured in PPSEU15.

${ }^{4}$ It should be stressed that the internal relative price indicator is also interpreted to a reference group: it shows how the price level of services is related to the price level of goods in the home country, as compared to the EU15.
} 


\subsection{Background and a selective review of the related literature}

Our article builds upon and contributes to a rich and prolific strand of research in international economics, namely, the literature on the relationship between economic growth and RER misalignments. Within this strand, our work is related to the line of research that interprets misalignments as deviations from the estimated price level of GDP consistent with the level of economic development. This approach involves three steps: (i) identifying the benchmark (or "neutral") RER, relative to which misalignment is interpreted; (ii) estimating the sign and size of the misalignments; and (iii) estimating the association between economic growth and indicator(s) of misalignment, controlling for other variables potentially affecting growth. In the following, we review the conceptual background of, and the literature related to, these steps.

2.2.1. The interpretation of the "neutral" RER: the PPP adjusted for the "Penn-effect". Our point of reference for interpreting RER-misalignments is the PPP, adjusted for the cross-country differences in relative levels of development. In its original form, the absolute version of the PPP theory of exchange rates claims that the equilibrium RER (ERER) corresponds to the PPP. ${ }^{5}$ In the following, we avoid the notion of ERER and focus at the background of adjusting the PPP for the level of development.

The idea that a positive relationship exists between the levels of (changes in) RERs and levels of (changes in) economic development has a long tradition, but the association between the two has first been statistically demonstrated, accompanied by a model-based explanation, in Balassa's (1964) seminal article on the reappraisal of the PPP theory. Samuelson (1964), independently from Balassa, also criticised the PPP-theory, relying on a similar model, and eventually the close positive association between national price and per capita GDP (income) levels came to be known as the "Balassa-Samuelson effect". Samuelson (1994), however, considered it important to clearly distinguish the observed statistical regularity, which he coined as the "Penneffect", ${ }^{6}$ from one of its possible explanations, i.e., the Balassa-Samuelson (BS) model. ${ }^{7}$

There are several layers of understanding/explaining the Penn-effect; here we refer only to two of these. ${ }^{8}$ One relates to the following question: the relative price of which particular GDPaggregate is chiefly responsible for the observed effect? In this respect, there has been a broad consensus among economists and economic statisticians: mainly the relative price level of services increases in line with the level of economic development (for earlier works see e.g., Harrod 1933; Clark 1940; Fourastié 1950; Kuznets 1971).

The second question concerns explanations of the observed effect. The most well-known is the BS model, which, building on rather restrictive assumptions, focuses on differences in productivity

\footnotetext{
${ }^{5}$ Cassel (1922). The PPP-theory implies that the equilibrium level of PL (PPP/E) is 1.

${ }^{6}$ Samuelson referred to the results of international comparisons performed in the framework of the ICP project in which the University of Pennsylvania had a major role. The PWT constitutes a major statistical source for worldwide comparisons of real GDP and its components. The data indicate a close positive association between the level of real incomes and relative price levels of GDP.

${ }^{7}$ The term "Balassa-Samuelson model" was suggested by Asea - Corden (1994). For reviews on alternative tests of the model, see e.g. Égert et al. (2006) and Tica - Druzic (2006).

${ }^{8}$ It should be noted that while the Penn-effect works among countries at considerably different levels of economic development, it does not appear to be significant within the most and the least developed group of countries; see Rogoff (1996) and Hassan (2016) on this point.
} 
between tradables (approximated by goods) and non-tradables (approximated by services), and attributes the differences in overall price levels to the higher productivity of producing goods relative to services in more advanced economies. The discussion on the relevance of the "productivity channel" has continued ever since its exposition. ${ }^{9}$ An alternative explanation was offered by Bhagwati (1984), who built his model on differences in factor endowments of the two sectors.

There is, however, a long tradition of explanations from the demand side as well (in particular, Fourastie 1950), but there were several later attempts in this vein (e.g., Bergstrand 1991; Podkaminer 2011). Bergstrand's model was based on the assertion that services are "luxury goods" while tradable commodities are "necessities". Therefore, as national income grows, the demand for services increases more than that for goods, which results in an appreciation of the RER. His results supported the hypothesis that, beside the supply-side, there is a demand-side channel responsible for the observed regularity. With respect to the catching-up process within the EU, Égert (2010) also provided evidence for the importance of the demand-side channel.

In the further part of the study we do not deal with alternative explanations; we simply consider the Penn-effect as a statistically firmly based stylized fact, which, as documented in Section 2.3, certainly holds for the EU27 in the period in our focus.

2.2.2. Estimating RER-misalignments and their effect on economic growth. Several studies discussed the implications of exchange rate misalignments, in particular, the negative effects of overvaluations on economic growth in the developing countries. ${ }^{10}$ There were some earlier attempts to combine the relationship between price levels and levels of economic development with differences in growth performances (Dollar 1992). However, the notion that deviations of RERs from levels implied by the "Penn effect" may be interpreted as RER-misalignments, capable to explain differences in growth rates, became popular and gained broader professional interest only in the late 2000s (Gala 2008, Eichengreen 2008, Podkaminer 2010, 2017; Rodrik 2008). ${ }^{11}$ Recent studies (e.g., Habib et al., 2017), similarly to the previous ones, found evidence that misalignments are negatively related to economic growth, but they also found, similarly to Rodrik (2008), that these results hold mainly for the less developed countries and do not apply for the countries at higher levels of economic development. For the Eurozone countries, Fischer (2007) and Andersson et al. (2009) estimate relationship between the price level and economic development. For the CEEU countries, Cuestas et al., 2019 estimate the effect of the RER misalignment on growth in a two-step method for the 1995-2012 period, using quarterly data. However, they use real effective exchange rate indexes, that is, rely on within country variation in estimating misalignment and do not use cross-country differences in relative price levels. They also find that the overvaluation is harmful for growth, however, undervaluation has had only a limited impact on economic activity.

\footnotetext{
${ }^{9} \mathrm{~A}$ thorough review of the related literature is provided by Devereux (2014). For a recent contribution, challenging the notion that higher productivity growth is accompanied by the RER-appreciation, see Gubler - Sax (2019).

${ }^{10}$ See e.g., Cavallo et al. (1990), Dollar (1992), Razin - Collins (1997), Benaroya - Janci (1999), Acemoglu et al. (2002), Fajnzylber et al. (2002).

${ }^{11}$ It should be noted that while several endeavours had been made to explain the underperformance of particular developed economies by RER-overvaluations (see in particular Kaldor $(1966,1971)$ on the UK and Corden (1984) on the "Dutch disease"), these interpretations did not refer to misalignments of RERs from the levels implied by the level of development.
} 
The results, naturally, depend on the way of calculating RER-misalignments. Balassa (1964) used a simple linear functional form, but later studies used a log-log form (Rogoff 1996, or Rodrik 2008), or a quadratic form (Dollar 1992 or Easterly 2001), while Bhalla (2012) estimated an "S-shaped" exponential model. The results are also sensitive to the chosen econometric method. Some authors estimated the misalignment using cross-sectional data for each year (e.g., Johnson et al. 2007), while others applied advanced panel techniques (Prasad et al. 2007; Rodrik 2008; MacDonald - Vieira 2010).

Several authors argued that the benchmark ("neutral") RER is not only the function of the level of development; but they also suggested the inclusion of other variables in the equation for the estimation RER-misalignment. For example, Aguirre - Calderon (2005) controlled for differences in the terms of trade index, labour productivity and government spending in their RER equation. Depending on the included control variables, the estimation technique, the underlying assumptions and simplifications, many different concepts have been established for interpreting RER-misalignments (Isard 2007; Berg - Miao 2010).

We summarised the results of some of the related studies in Table 1 (online). The table shows the method applied, the sample chosen and the findings of the authors with respect to the estimated RER, as well as the estimated effect of misalignment. The works included in the table aim to clarify and compare (i) the estimated long-term relationship between different concepts of the RER and economic fundamentals, most importantly, the level of economic development; (ii) the effect of misalignment of the RER from its development-consistent value on growth, or both. The third column of Table 1 confirms that there is a large variety of methods applied for estimating misalignments.

The effect of misaligned RER is usually measured by adding in some form of the estimated misalignment to a growth regression, in addition to the usual variables affecting economic growth. Most approaches add the contemporary value of the misalignment. The majority of studies find that the overvalued RERs hamper growth contemporaneously, but there are exceptions. For example, Easterly (2001) found that if the extreme values are excluded from the sample, overvaluation does not have detrimental effects. Bereau et al. (2012) do not support this finding, but call attention to the non-linearities: larger misalignments have disproportionally larger effect. Most papers find that the direction of the deviation from the estimated benchmarkRER is symmetric in the sense that overvaluation is harmful and undervaluation is beneficial for growth. ${ }^{12}$ This is the finding of Berg and Miao (2010) as well, but they also point out an identification problem: the same factors that contribute to growth, may also contribute to the RER-changes and their misalignments.

The foregoing review, along with Table 1, shows the variety of methods for estimating the level of RER consistent with the level of development, as well as the differences among the

\footnotetext{
${ }^{12}$ Similarly to Berg - Miao (2010), we use the term "symmetric effect" of misalignments in the above sense, though we are aware that "symmetry" is sometimes considered to imply that both under- and overvaluations are harmful for growth. This, however, would involve an asymmetry in the sense that misalignments with a negative and a positive sign would both have a negative effect on growth.
} 
findings of studies concerning the relationship between RER misalignment and economic growth, based on different samples and time periods. In the following, we focus on the EU.

\subsection{Stylized facts ${ }^{13}$}

In this section we demonstrate the close positive association within the EU between the price level of GDP (the overall RER) and the internal relative price of services to goods (the internal RER) on the one hand, and relative per capita GDP (the level of income), on the other. We also show that the first relationship (the Penn-effect) holds much more closely within the EU than worldwide. Finally, we document that the changes in GDP price levels relative to the EU15 average (our indicator of the overall RER) are closely associated with the changes in the GDP deflator-based real effective exchange rate (REER) index against 42 industrial countries. This finding suggests that our indicator of the overall RER represents relative price movements compared to a much broader set of countries than those belonging to the EU.

Fig. 1 shows the association between the price level of GDP and per capita GDP in 27 EUmember states ${ }^{14}$ relative to the EU15, based on the pooled cross section of the observations for the period of 1995-2016.

Fig. 1 - reflecting the Penn-effect - shows that the association between the two variables is indeed rather close $\left(\mathrm{R}^{2}=0.88\right.$ ), and the coefficient of per capita GDP (significant at $1 \%$ ) shows that, on average, one per cent higher (lower) real income is accompanied by a 0.85 per cent higher (lower) GDP price level. If we regress GDP price level on GDP per worker (an indicator of labour productivity) for the same sample, we get a slightly higher elasticity, close to 0.9 ( $R^{2}$ is almost the

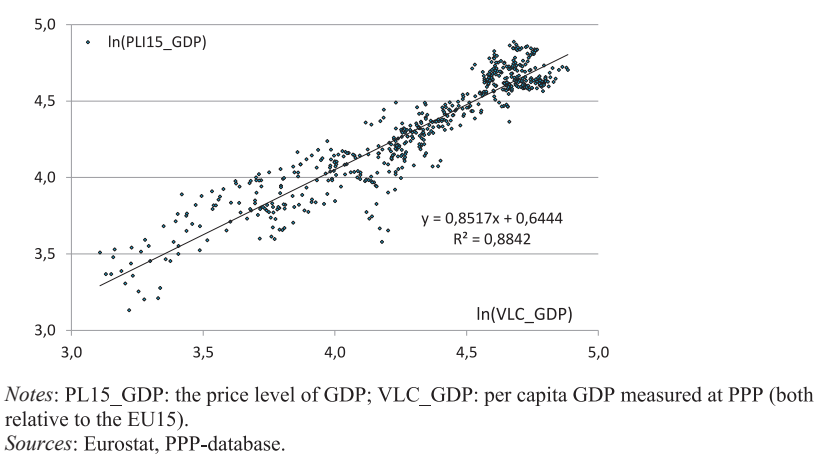

Fig. 1. The relationship between the price level of GDP and per capita GDP (measured at PPP) within the EU (pooled cross-section data, 1995-2016; EU15 = 100)

\footnotetext{
${ }^{13}$ We use the term "stylized facts" more broadly than as introduced by Kaldor (1961). We refer to statistical observations underlying and motivating, rather than to observations meant to be actually explained by, our analysis. See Skidelsky (2017) on Kaldor's original interpretation of the term.

${ }^{14}$ Luxembourg, an extreme outlier, is not included in our sample.
} 


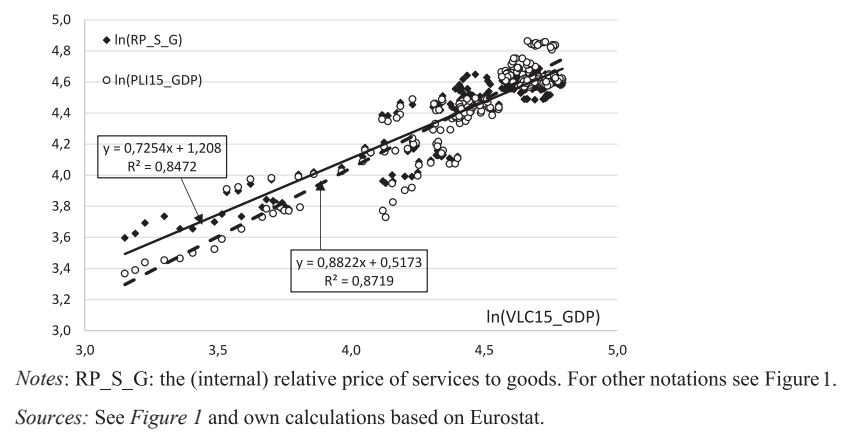

Fig. 2. The relationship between the price level of GDP, the internal relative price of sewices to goods (vertical axis) and per capita GDP (measured at PPP) within the EU (pooled cross-section, 1999-2016; EU15 = 100)

same: 0.86), indicating that the close relationship between the GDP price level and the level of development does not depend on whether the latter is represented by real income or productivity.

Fig. 2, beside the GDP price level, includes the pooled cross-section observations on the relative price of services to goods (the internal RER) as well, for the years of 1999-2016, the period for which data regarding both overall and internal RERs are available for our full sample of 27 EU-countries. The elasticity of the internal RER to the level of income is somewhat lower (0.73) than that of the overall RER (0.88), but both RER-indicators are very closely related to real income. ${ }^{15}$ We consider the points on the regression lines, similarly to Fig. 2, as an alternative expression of RERs consistent with the level of income. Deviations from the developmentconsistent levels serve as the references for interpreting and measuring the alternative indicators of RER-misalignments: downward (upward) alterations are, respectively, interpreted as under (over-) valuations of the RER. ${ }^{16}$

Next, drawing on the PWT $9.0^{17}$, we show the relationship between the price level of GDP and per capita real GDP for a large sample of countries with population size above 1 million, and contrast the results with those for the EU25 (Fig. 3 - online).

The levels are expressed relative to the US and the data relate to 2014, the last year covered by PWT.9.0. In the broad sample for 2014, consisting of almost 150 countries (upper panel), the elasticity of the GDP price level with respect to relative income is 0.23 (significant at $1 \%$ ), with a $\mathrm{R}^{2}$ of 0.41 . This result, confirming the existence of the Penn effect, is quite similar to other findings in the literature, based on a large sample of countries, covering longer periods, generally relying on panel data, but ending before 2014 (the corresponding results of several other papers are

\footnotetext{
${ }^{15}$ This is similar to the much earlier results of Kravis - Lipsey (1983). Berka - Devereux (2013) also documented the close association between relative price and income levels within the EU for the period of 1995-2009. They quantified the aggregate internal RER as the relative price of non-tradables to tradables, based on a selection of items at the lowest level of aggregation. Their results are similar to ours, suggesting that at the aggregate level there is a rather close correspondence between the relative price of non-tradables to tradables on the one hand, and services to goods, on the other.

${ }^{16}$ The actual regressions estimated in Section 3 differ from the ones illustrated in Fig. 2, as our estimates contain year dummies and we apply the DOLS method by adding short term dynamic terms to the regression.

${ }^{17}$ PWT (2017), see also Feenstra et al. (2015).
} 
summarised in Table 1 - online). As shown by the lower panel, the pattern reflecting the relationship between price levels and relative incomes among 25 EU-countries included in our sample, based on the $\mathrm{PWT}^{18}$, matches the world-wide pattern, but the elasticity of the price level (0.89) and the $\mathrm{R}^{2}(0.80)$ is significantly higher within the EU than among the countries included in the broad sample. This indicates that the Penn-effect "works" much more forcefully among the EU memberstates, closely integrated by trade, capital and labour flows than what we observe worldwide. It also suggests that measuring RER-misalignments by deviations from PPPs adjusted for the Penn-effect may be more relevant among the EU member-states than for the large sample of countries.

The differences in the residuals of the regressions illustrated in the upper and lower panel of Fig. 3, are shown in Fig. 4 (online). The comparison of the residuals (which, by definition, imply zero misalignment for the EU within EU-comparisons) indicates that the EU25 as a whole is by 20 per cent overvalued as compared to the broad international sample. The differences are particularly striking regarding the most developed EU-countries. While, in 2014, the RERs of four developed economies (Austria, Germany, Ireland and the Netherlands) are found to have been undervalued in the European context, the same countries' RERs are estimated to be grossly overvalued when the large sample of countries is considered as a reference. The differences between the two types of estimations of misalignment for the advanced EU-countries are extremely large (40-55 percentage points). These massive differences are likely to explain why previous studies, relying on samples consisting of both underdeveloped and highly developed economies, concluded that RER misalignments have insignificant effect on economic growth in the advanced economies. According to our results, based on the sample of the EU27 (Section 4), there is no evidence of a significant difference in the growth effect of misalignments between the less and more affluent countries.

Finally, we draw attention to the fact that the changes in our measure of the overall RER, that is, the price level of GDP relative to the EU15 average, are closely correlated with the changes in GDP deflator-based REER indices measured against the average of a broader set of 42 countries, representing the bulk of the competitors. Fig. 5 (online) suggests that, for the EU as a whole, the changes in RERs in our interpretation represent changes in REERs in the broader interpretation as well.

\section{INTERPRETING AND MEASURING REAL EXCHANGE RATE (RER) MISALIGNMENT}

In the present section we calculate alternative measures of RER-misalignment. As discussed in Section 2, we rely on two concepts of the RER: the price level of GDP and the internal relative price of services to goods. With respect to the level of development, we apply real income (GDP per capita) and real productivity (GDP at PPP per persons employed) as indicators. We interpret RER-misalignment as the deviation of an actual RER from the level consistent with the relative real income/productivity of a country.

Our approach basically follows the method based on PPP adjusted for the relative level of development, but similarly to e.g., Aguirre - Calderon (2005), Galstyan - Lane (2009) and others, we also consider other fundamental control variables that relate our method to the BEER

\footnotetext{
${ }^{18}$ Since the population of Cyprus and Malta is below 1 million, they are not included in our sample.
} 
approach. ${ }^{19}$ We use single equation panel cointegration regressions to estimate the long termrelationship between the level of development and RER indicators. We estimate the relationship using panel data for the period of 1995-2016 for $27 \mathrm{EU}$ countries. ${ }^{20}$

The literature is ambivalent with respect to using country fixed effects in the panel estimation, as the choice between adding or omitting fixed effects can be characterized by a trade-off. On the one hand, by applying fixed country constants, one practically loses the cross-country variation of RERs, and the long-term relationship is identified only from within the variation. The fixed effects actually imply that the misalignment is zero in all countries in the average of the period, but this is a very strong assumption, taking into account that our sample covers only 22 years. On the other hand, without fixed country effects, the estimated misalignment might also contain long term country-specific factors that arise e.g. from compositional or methodological differences (or related to other unobserved characteristics) rather than from mispricing. Given that the zero misalignment assumption seems to be quite restrictive and not realistic in our short sample, while betweencountry variation explains the bulk of the total variation in our RER and development-level variables, our baseline model, similarly to e.g. Rodrik (2008), does not include country specific constants. However, as a robustness check, we also present fixed effect estimations.

The long-term relationships are calculated with the Dynamic OLS (DOLS) method, as this method accounts for the serial correlation and heteroscedasticity of the residual by adding the leads and lags of the differenced independent variable to the regression. ${ }^{21}$ All coefficients are presented with robust standard errors.

The DOLS specification with fixed time effects is the following:

$$
\log \left(R E R_{t i}\right)=\alpha_{t}+\beta \log \left(G D P_{t i}^{R E L}\right)+\Gamma \boldsymbol{X}_{t i}+\sum_{j=-1}^{1} \delta_{j} \Delta \log \left(\boldsymbol{X}_{t+j, i}\right)+\sum_{j=-1}^{1} \theta_{j} \Delta \log \left(G D P_{t+j, i}^{R E L}\right)+\varepsilon_{i t}
$$

$R E R_{t i}$ stands for two different measures of the real exchange rate of country $i$ in year $t$, namely: (i) the relative price level of GDP measured at current PPP $\left(P L g d p_{t i}\right)$; and (ii) the internal relative price of services to goods $\left(R P_{\text {sgti }}\right)$; all relative prices are compared to the average of the EU15. $\boldsymbol{X}_{t i}$ stands for the control variables.

$G D P_{t i}^{R E L}$, in turn, denotes two different measures of the level of economic development of country $i$ in year $t$, relative to the EU15 average: (i) per capita GDP at current PPP $\left(V L C g d p_{t i}\right)$; and (ii) GDP per persons employed, at current PPP ( $\left.V L W g d p_{t i}\right)$.

Misalignment is measured as the deviation of the actual RER from its long term predicted value by the above regression.

$$
\text { Misal }_{t i}=\log \left(R E R_{t i}\right)-\log \left(\widehat{R E R}_{t i}\right)
$$

where:

\footnotetext{
${ }^{19}$ On the "behavioural equilibrium exchange rate" (BEER) see Clark - Mcdonald (1999).

${ }^{20}$ For reasons discussed earlier, Luxembourg is not included in our sample.

${ }^{21}$ The sample period is short and the number of a cross-sections is large so the power of unit root and cointegration tests is low and sensitive to the number of lags, but the majority of the tests confirmed cointegration between the variables in the long-term equation.
} 
Table 2. The long-term relationship between the price level of GDP or the internal relative price of services to goods indicators and the level of economic development

\begin{tabular}{|c|c|c|c|c|c|c|c|c|}
\hline \multirow[b]{3}{*}{ Dependent var. } & (1) & (2) & (3) & (4) & (5) & (6) & (7) & (8) \\
\hline & \multicolumn{4}{|c|}{$\log$ gdp } & \multicolumn{4}{|c|}{ log_rp_s_g } \\
\hline & & controls & & controls & & controls & & controls \\
\hline \multirow[t]{2}{*}{ log_vlc15_gdp } & $0.854 * * *$ & $0.800 * * *$ & & & $0.656 * * *$ & $0.654 * * *$ & & \\
\hline & $(0.016)$ & $(0.016)$ & & & $(0.015)$ & $(0.019)$ & & \\
\hline \multirow[t]{2}{*}{ log_vlw15_gdp } & & & $0.906 * * *$ & $0.841 * * *$ & & & $0.715^{* * *}$ & $0.715^{* * *}$ \\
\hline & & & $(0.021)$ & $(0.02)$ & & & $(0.023)$ & $(0.028)$ \\
\hline \multirow[t]{2}{*}{ nxdebt_gdp } & & $-0.011 * *$ & & $-0.008^{* *}$ & & $-0.014 * * *$ & & $-0.010 * *$ \\
\hline & & $(0.004)$ & & $(0.003)$ & & $(0.005)$ & & $(0.005)$ \\
\hline \multirow[t]{2}{*}{ Intot_eff } & & -1.882 & & 0.477 & & -1.842 & & 0.100 \\
\hline & & $(1.603)$ & & $(1.697)$ & & $(1.275)$ & & $(1.552)$ \\
\hline \multirow[t]{2}{*}{ open } & & $-0.257 * * *$ & & $-0.255^{* * *}$ & & $-0.317 * * *$ & & $-0.330 * * *$ \\
\hline & & $(0.025)$ & & $(0.027)$ & & $(0.032)$ & & $(0.034)$ \\
\hline \multirow[t]{2}{*}{ gov_gdp } & & $0.016 * * *$ & & $0.0192 * * *$ & & 0.002 & & $0.006 * * *$ \\
\hline & & $(0.002)$ & & $(0.002)$ & & $(0.002)$ & & $(0.002)$ \\
\hline \multirow[t]{2}{*}{ Constant } & $0.612^{* * *}$ & $0.606 * * *$ & $0.380 * * *$ & $0.373 * * *$ & $1.588^{* * *}$ & $1.669 * * *$ & $1.310 * * *$ & $1.307 * * *$ \\
\hline & $(0.075)$ & $(0.069)$ & $(0.091)$ & $(0.0985)$ & $(0.075)$ & $(0.082)$ & $(0.107)$ & $(0.122)$ \\
\hline Observations & 591 & 535 & 591 & 535 & 535 & 496 & 535 & 496 \\
\hline R-squared & 0.891 & 0.916 & 0.860 & 0.891 & 0.850 & 0.893 & 0.821 & 0.879 \\
\hline Year FE & YES & YES & YES & YES & YES & YES & YES & YES \\
\hline
\end{tabular}

Notes: Clustered standard errors in parentheses $* * * P<0.01, * * P<0.05, * P<0.1$. log_vlc15_gdp: the log of relative per capita GDP measured at PPP, EU15 = 100. log_vlw15_gpd:log of relative per worker GDP measured at PPP, EU15 $=100$. log_pl_gdp:log of price level of GDP, measured at current PPP, EU15 = 100. log_r_p_sg: log of relative price of services to goods, EU15 = 100. gov_gdp: government consumption/GDP. open: openness (import + export)/GDP. nx_debt: net external debt/GDP. Intot_eff: the effect of changes in the terms of trade on the change in real gross domestic income. 
Table 3. Summary statistics of different measures of RER misalignment

\begin{tabular}{|l|c|c|c|c|c|}
\hline Variable & Obs & Mean & Std.dev & Min & Max \\
\hline mis_rp_vlc & 536 & -0.023 & 0.109 & -0.321 & 0.282 \\
\hline mis_rp_vlw & 536 & -0.017 & 0.109 & -0.372 & 0.329 \\
\hline mis_pl_vlc & 589 & -0.004 & 0.113 & -0.606 & 0.254 \\
\hline mis_pl_vlw & 589 & -0.002 & 0.127 & -0.464 & 0.354 \\
\hline mis_rp_vlc_w/controls & 508 & -0.023 & 0.109 & -0.333 & 0.256 \\
\hline mis_rp_vlw_w/controls & 508 & -0.016 & 0.111 & -0.374 & 0.329 \\
\hline mis_pl_vlc_cont w/controls & 550 & -0.009 & 0.115 & -0.566 & 0.290 \\
\hline mis_pl_vlw_cont w/controls & 550 & -0.009 & 0.129 & -0.464 & 0.349 \\
\hline
\end{tabular}

Notes: mis_rp_vlc and mis_rp_vlw stand for the estimated misalignment in internal relative price, the benchmark variable is the relative per capita and per employed person GDP respectively.

The average of misalignments is close, but not equal, to zero, as the dynamic terms do not count into the neutral RER, hence the misalignments are not equal with the residuals of the regressions (see footnote 20).

$$
\log \left(\widehat{R E R}_{t i}\right)=\widehat{\alpha}_{t}+\widehat{\beta} \log \left(G D P_{t i}^{R E L}\right)+\widehat{\Gamma} X_{t i}
$$

$\log \left(\widehat{R E R}_{t i}\right)$ is the natural logarithm of the level of the RER which is consistent with the level of development. We shall refer this level as a "neutral" RER.

Note that in the DOLS specification, the differenced terms are not accounted for the longterm relationship. ${ }^{22}$

Based on the literature, we add the following controls in the equation of the long-term relationship: the impact of the terms of trade on domestic income, government consumption, net external debt and openness. However, even if these variables are significant determinants of the RER in the long term, it is not evident whether these factors alter the development-consistent, neutral RER. In the following, we present estimations of the misalignments both with and without the control variables.

Overall, the control variables do not add much to the model in terms of explanatory power. The level of relative economic development, alternatively measured, seems to be the major determinant of variations in alternatively defined RERs (Table 2). However, the misalignment estimated with the regression extended with controls differs significantly from the simple misalignment in the case of a few countries.

Table 3 shows the basic summary of descriptive statistics for the four measures of RERmisalignment used in our growth regressions. As it can be seen, estimated misalignments vary in a relatively wide range and the standard deviation is sizable, $11-13 \%$.

To sum up, as compared to the results of the related literature covering a larger sample of countries, the long term coefficient between the GDP price level and relative indicators of development, as well as the explanatory power of economic development in the price level of GDP

\footnotetext{
${ }^{22}$ The role of leading and lagged dynamic terms is to give an asymptotically efficient estimation for the long-term parameter by eliminating the feedback in the cointegrating system.
} 
and internal relative prices can be regarded as high in our sample including the EU27. Per capita income or labour productivity explains the bulk of the variation in relative price developments.

The relationship between the relative GDP variables and relative internal prices is comparably strong with the slope being less steep. However, for some countries, the misalignment implied by the internal relative price differs significantly from the one estimated using the GDP price level.

As a robustness check, we present results from the cross-country estimations estimated year by year to present the evolution of the estimated parameter of GDP per capita. For this comparison, we present the simplest panel estimations with fixed time effect and no control variables. As Fig. 6 (online) shows, the estimated long term coefficient of relative development (measured by per capita GDP) from the panel estimation lies in the confidence interval of the cross-country estimations in the entire period. This stability enables us to apply the same model for the whole sample period.

\section{THE RELATIONSHIP BETWEEN RER-MISALIGNMENTS AND ECONOMIC GROWTH}

\subsection{Our approach}

In this section we investigate the relationship between RER-misalignments and growth. The novelty of our approach is that we systematically compare the growth effect of misalignments based on the measures relying on both the relative price level of GDP and the internal relative price of services to goods and also apply different estimation techniques as a robustness check. Furthermore, we address the heterogeneity in the growth effects of misalignment with respect to the exchange rate regime, the sign and size of the misalignment, as well as the level of development.

Our basic specification is the following ${ }^{23}$ :

$$
d \log \left(Y_{t i}\right)=\eta_{t}+\rho d \log \left(Y_{t-1}\right)+\zeta \log \left(G D P_{T 0, i}^{R E L}\right)+\Phi Z_{t i}+\gamma M_{i s a l}+\varepsilon_{i t}
$$

where

$d \log \left(Y_{t i}\right)$ denotes economic growth of country $i$ in year $t$. Basically we use annual growth rate of GDP per capita at constant (2010) prices $\left(Q C_{-} g d p_{t i}\right)$.

$\log \left(G D P_{T 0, i}^{R E L}\right)$ is the value of the per employed GDP relative to the EU15, measured at current PPP in the first year of 5 year blocks: 1995, 2000, 2005, 2010 and 2015. This variable captures the effect of beta convergence.

$Z_{t i}$ stands for the following control variables. Free: Heritage Foundation economic freedom index; Infl: HICP, annual rate of change; Gov_def: deficit of consolidated government as a \% of GDP; and Inv $g d p$ : fixed capital formation as a \% of GDP. The other control variables used in the literature proved to be insignificant, and as the data coverage was not full for these variables, we decided to drop them from the estimation (years of education, life expectancy and terms of trade).

\footnotetext{
${ }^{23}$ This specification is similar to Rodrik (2008), however, he adds country fixed effect instead of lagged dependent variable to the equation.
} 
Misal $_{t i}$ represents RER-misalignment measured in four different ways. The specific indicators differ along two dimensions, as we use two different RER indicators and two different concepts for the level of development. Accordingly, we calculate the misalignment of the (i) price level of GDP and that of the (ii) internal relative price, which, in turn, are interpreted as the deviation of an actual RER from the level consistent with relative development of a country. As a baseline, we present results of estimation with misalignments interpreted as deviations from the levels consistent with productivity (GDP per worker). Results with per capita income-based misalignments are presented in the Appendix (Tables A5-A12). The misalignment shows up with its sign in the regression, what is consistent with the assumption that overvaluation has the opposite effect as undervaluation. We also analyse asymmetry with respect to the sign of the misalignment later.

Our baseline results rest on the estimated misalignments in which the long-term relationship is calculated without control variables, that is, relying only on the relationship between the RER and the respective indicator of relative development. The reason is that the models with controladjusted misalignments have lower explanatory power; these indicators proved to be insignificant in most of the cases, suggesting that simple misalignments are more closely related to growth than control-adjusted misalignments.

Adding the contemporaneous misalignment as an explanatory variable raises the danger of endogeneity. Indeed, the RER is an endogenous variable, the direction of causality from/towards growth is not straightforward and the same shock might influence both variables. For example, if a negative GDP shock reduces growth, and if prices and the exchange rates react with a lag, this will move misalignment upwards (toward overvaluation) and might bias the coefficient in the negative direction. We address the endogeneity problem by mainly two specifications. In the first, we add lagged misalignment instead of its contemporaneous value. An important feature of the specification with lagged misalignment is that the potential bias arising from the contemporaneous shocks affecting growth and misalignment at the same time is ruled out, and the indirect effect through lagged growth is captured by the lagged dependent variable.

Similarly to e.g., Rodrik (2008) and Aguirre - Calderon (2005), we also estimate a system GMM model in spirit of Blundell - Bond (1998), where the misalignment is explicitly treated as an endogenous variable. Here the instruments can be regarded as fully exogenous. ${ }^{24}$

As in the case of our first step estimations, a dilemma arises with respect to using fixed country effects in the growth regression. As Angrist. - Pischke (2009) show, in shorter samples, time invariant country specific factors (to be modelled by country fixed effects) on the one hand, and highly persistent, but not time invariant developments (to be modelled by lagged dependent variables) on the other, are hard to distinguish, so the fixed effect and lagged dependent variable can be regarded as boundaries of the true parameter. Adding both fixed effect and lagged dependent variable raises a new problem of dynamic panels: inconsistent estimation arising from correlation between the lagged dependent variable and the error term (Blundell - Bond

\footnotetext{
${ }^{24}$ In addition to the lagged dependent variable, the specification also includes the second lag of the dependent variable and the Arellano-Bond test statistic for the $\operatorname{AR}(2)$ in the first differences is not rejected in any specification.
} 
Table 4. Growth regressions. Dependent variable: annual growth rate of GDP per capita volume (dlog_qc_gdp)

\begin{tabular}{|c|c|c|c|c|c|c|c|c|}
\hline & (1) & (2) & (3) & (4) & (5) & (6) & (7) & (8) \\
\hline & \multicolumn{4}{|c|}{ GDP price level } & \multicolumn{4}{|c|}{ Internal relative price } \\
\hline & $\begin{array}{l}\text { Lagged } \\
\text { dependent } \\
\text { var. }\end{array}$ & $\begin{array}{l}\text { Fixed } \\
\text { effect }\end{array}$ & $\begin{array}{l}\text { System } \\
\text { GMM }\end{array}$ & $\begin{array}{l}\text { Lagged misal, } \\
\text { lagged dependent } \\
\text { var }\end{array}$ & $\begin{array}{l}\text { Lagged } \\
\text { dependent } \\
\text { var. }\end{array}$ & $\begin{array}{l}\text { Fixed } \\
\text { effect }\end{array}$ & $\begin{array}{l}\text { System } \\
\text { GMM }\end{array}$ & $\begin{array}{l}\text { Lagged misal, } \\
\text { lagged dependent } \\
\text { var }\end{array}$ \\
\hline \multirow[t]{2}{*}{ L.dlog_qc_gdp } & $0.424 * * *$ & & $0.232 * * *$ & $0.429 * * *$ & $0.407 * * *$ & & $0.220 * * *$ & $0.404 * * *$ \\
\hline & $(0.042)$ & & $(0.074)$ & $(0.041)$ & $(0.049)$ & & $(0.079)$ & $(0.045)$ \\
\hline \multirow[t]{2}{*}{ missal } & $-0.022 * * *$ & $-0.063^{* *}$ & $-0.035^{* *}$ & & $-0.020 * *$ & $-0.072^{*}$ & -0.025 & \\
\hline & $(0.007)$ & $(0.029)$ & $(0.016)$ & & $(0.008)$ & $(0.040)$ & $(0.021)$ & \\
\hline \multirow[t]{2}{*}{ L.misal } & & & & -0.009 & & & & $-0.012^{* *}$ \\
\hline & & & & $(0.006)$ & & & & $(0.006)$ \\
\hline \multirow[t]{2}{*}{ log_vlc15_gdp_i5 } & $-0.019 * * *$ & $-0.053 * * *$ & $-0.031 * * *$ & $-0.019 * * *$ & $-0.018^{* * *}$ & $-0.062 * * *$ & $-0.025 * * *$ & $-0.025 * * *$ \\
\hline & $(0.003)$ & $(0.013)$ & $(0.008)$ & $(0.003)$ & $(0.003)$ & $(0.013)$ & $(0.008)$ & $(0.003)$ \\
\hline \multirow[t]{2}{*}{ inv_gdp } & 0.015 & $0.219 * *$ & $0.212 * * *$ & 0.030 & $0.053^{*}$ & $0.282 * * *$ & $0.242 * * *$ & 0.042 \\
\hline & $(0.031)$ & $(0.088)$ & $(0.067)$ & $(0.031)$ & $(0.030)$ & $(0.087)$ & $(0.064)$ & $(0.026)$ \\
\hline \multirow[t]{2}{*}{ Infl } & $-0.007 * * *$ & $-0.007^{* *}$ & -0.057 & $-0.007 * * *$ & -0.023 & -0.051 & -0.100 & -0.051 \\
\hline & $(0.002)$ & $(0.003)$ & $(0.038)$ & $(0.002)$ & $(0.032)$ & $(0.050)$ & $(0.066)$ & $(0.044)$ \\
\hline \multirow[t]{2}{*}{ gov_def } & $-0.122 * * *$ & $-0.207 * * *$ & $-0.436 * * *$ & $-0.105^{* * *}$ & $-0.084^{* *}$ & $-0.150^{*}$ & $-0.430 * * *$ & $-0.087^{* *}$ \\
\hline & $(0.035)$ & $(0.059)$ & $(0.141)$ & $(0.036)$ & $(0.036)$ & $(0.081)$ & $(0.137)$ & $(0.037)$ \\
\hline \multirow[t]{2}{*}{ Free } & $0.043^{*}$ & -0.010 & -0.016 & 0.037 & 0.036 & -0.042 & -0.060 & $0.040^{*}$ \\
\hline & $(0.021)$ & $(0.079)$ & $(0.075)$ & $(0.022)$ & $(0.023)$ & $(0.085)$ & $(0.067)$ & $(0.021)$ \\
\hline
\end{tabular}

(continued) 
Table 4. Continued

\begin{tabular}{|c|c|c|c|c|c|c|c|c|}
\hline & (1) & (2) & (3) & (4) & (5) & (6) & (7) & (8) \\
\hline & \multicolumn{4}{|c|}{ GDP price level } & \multicolumn{4}{|c|}{ Internal relative price } \\
\hline & $\begin{array}{l}\text { Lagged } \\
\text { dependent } \\
\text { var. }\end{array}$ & $\begin{array}{l}\text { Fixed } \\
\text { effect }\end{array}$ & $\begin{array}{l}\text { System } \\
\text { GMM }\end{array}$ & $\begin{array}{l}\text { Lagged misal, } \\
\text { lagged dependent } \\
\text { var }\end{array}$ & $\begin{array}{l}\text { Lagged } \\
\text { dependent } \\
\text { var. }\end{array}$ & $\begin{array}{l}\text { Fixed } \\
\text { effect }\end{array}$ & $\begin{array}{c}\text { System } \\
\text { GMM }\end{array}$ & $\begin{array}{l}\text { Lagged misal, } \\
\text { lagged dependent } \\
\text { var }\end{array}$ \\
\hline \multirow[t]{2}{*}{ Constant } & $0.084 * * *$ & $0.220 * * *$ & $0.132 * * *$ & $0.080 * * *$ & $0.077^{* * *}$ & $0.268 * * *$ & $0.131 * * *$ & $0.107 * * *$ \\
\hline & $(0.014)$ & $(0.062)$ & $(0.048)$ & $(0.015)$ & $(0.014)$ & $(0.074)$ & $(0.045)$ & $(0.015)$ \\
\hline Observations & 538 & 564 & 511 & 538 & 508 & 522 & 494 & 495 \\
\hline R-squared & 0.681 & 0.602 & & 0.675 & 0.696 & 0.637 & & 0.727 \\
\hline
\end{tabular}

Notes: Clustered standard errors in parentheses ${ }^{* * * P}<0.01,{ }^{* *} P<0.05,{ }^{*} P<0.1$. 
1995). This can be cured by instrumenting the lagged dependent variable in a system or difference GMM estimation. ${ }^{25}$

Based on the above considerations, to ensure robustness and address the problem of endogeneity, we present the following models. (1) lagged dependent variable with contemporaneous misalignment, (2) fixed effect specification with contemporaneous misalignment, (3) system GMM with lagged dependent variable, (4) lagged misalignment with lagged dependent variable and (5) with country fixed effect. In (6), (7), (8) the fixed effect specification is estimated with misalignments based on the country fixed effect specifications. Results of the specifications (5), (6), (7), (8) are presented in the Appendix (Tables A1-A4).

We apply year fixed effects in every specification. The standard errors are clustered by country in order to control for autocorrelation of the residuals.

\subsection{Baseline results}

Table 4 shows the results of our baseline growth regressions based on the level of the contemporaneous misalignment for the EU27. The parameter is negative in all specifications, indicating, in line with the common finding in the literature, that an under/overvalued RER relative to its development-consistent, "neutral" level - is positively/negatively associated with contemporaneous growth. However, the parameter of misalignment is insignificant in some of the specifications, i.e., the results are not fully robust to the specification for the sample as a whole. Misalignments based on the GDP price level and the internal relative price behave similarly.

In line with our convergence estimations, the initial level of development - the relative GDP per capita in the first year of 5-year blocks ( $\left.\log _{-} v l c 15 \_g d p \_i 5\right)$ - is highly significant in all specifications; the value of the parameter is higher in case of per capita items. This result is robust to the variable applied for measuring the "initial" level of development: both beta convergence and other variables are similar when using the relative per capita GDP of the first year of the sample (1995 or 2009) or that of the previous year. ${ }^{26}$

\subsection{Heterogeneity in the effect of the misalignment: the exchange rate regime, non- linearity and the CEEU-countries}

4.3.1. Fixed vs. floating exchange rate regime countries. The question arises whether the relationship between misalignments and growth depends on the exchange rate (ER) regime. This question is tested by adding the interaction term of the misalignment with the dummy variable that equals when the ER is fixed vis-à-vis the euro. The classification of fixed ER cases is in Appendix A16. Our estimation shows that the negative effect of misalignment on growth is attributable mainly to the countries with fixed ERs, moreover, as Table 5 shows, the growth

\footnotetext{
${ }^{25}$ If the data generating process is the lagged dependent variable but modelled with fixed effect, the model might overestimate the effect of misalignment, and the estimated parameter could be biased downward if a fixed effect model is incorrectly estimated by the lagged dependent variable.

${ }^{26}$ The effect of inflation, government deficit and investment/GDP is similar in the fixed effect specifications, that is, when only the within variation is used for identification. However, economic freedom usually loses significance in the fixed effect models, as the within variation is much less important at this variable.
} 
Table 5. Estimates of asymmetric effects of misalignment: fixed exchange rate countries. Dependent variable: annual growth rate of GDP per capita volume (dlog_qc_gdp)

\begin{tabular}{|c|c|c|c|c|c|c|c|c|}
\hline & (1) & (2) & (3) & (4) & (5) & (6) & (7) & (8) \\
\hline & \multicolumn{4}{|c|}{ GDP price level } & \multicolumn{4}{|c|}{ Internal relative price } \\
\hline & $\begin{array}{l}\text { Lagged } \\
\text { dependent } \\
\text { var. }\end{array}$ & $\begin{array}{l}\text { Fixed } \\
\text { effect }\end{array}$ & $\begin{array}{l}\text { System } \\
\text { GMM }\end{array}$ & $\begin{array}{l}\text { Lagged misal, lagged } \\
\text { dependent var }\end{array}$ & $\begin{array}{c}\text { Lagged } \\
\text { dependent } \\
\text { var. }\end{array}$ & $\begin{array}{l}\text { Fixed } \\
\text { effect }\end{array}$ & $\begin{array}{l}\text { System } \\
\text { GMM }\end{array}$ & $\begin{array}{l}\text { Lagged misal, lagged } \\
\text { dependent var }\end{array}$ \\
\hline \multirow[t]{2}{*}{ misal } & -0.001 & -0.036 & 0.020 & & 0.003 & -0.033 & 0.014 & \\
\hline & $(0.008)$ & $(0.023)$ & $(0.015)$ & & $(0.011)$ & $(0.030)$ & $(0.025)$ & \\
\hline \multirow[t]{2}{*}{ fixer } & $-0.003^{*}$ & $-0.009 *$ & $-0.008^{*}$ & & $-0.004^{* *}$ & $-0.010 * *$ & $-0.009 *$ & \\
\hline & $(0.002)$ & $(0.005)$ & $(0.005)$ & & $(0.002)$ & $(0.005)$ & $(0.005)$ & \\
\hline \multirow[t]{2}{*}{ misal*fixer } & $-0.047 * * *$ & $-0.088 * * *$ & $-0.095 * * *$ & & $-0.050 * *$ & $-0.089 * * *$ & $-0.083^{* *}$ & \\
\hline & $(0.016)$ & $(0.024)$ & $(0.028)$ & & $(0.020)$ & $(0.020)$ & $(0.036)$ & \\
\hline \multirow[t]{2}{*}{ L.misal } & & & & $0.013^{*}$ & & & & 0.005 \\
\hline & & & & $(0.007)$ & & & & $(0.011)$ \\
\hline \multirow[t]{2}{*}{ L.fixer } & & & & -0.002 & & & & -0.002 \\
\hline & & & & $(0.002)$ & & & & $(0.002)$ \\
\hline \multirow[t]{2}{*}{ L.misal*I.fixer } & & & & $-0.054 * * *$ & & & & $-0.040 * *$ \\
\hline & & & & $(0.015)$ & & & & $(0.018)$ \\
\hline Controls & YES & YES & YES & YES & YES & YES & YES & YES \\
\hline Observations & 538 & 564 & 511 & 538 & 508 & 522 & 494 & 495 \\
\hline R-squared & 0.689 & 0.625 & & 0.686 & 0.704 & 0.652 & & 0.732 \\
\hline
\end{tabular}

Notes: Clustered standard errors in parentheses ${ }^{* * *} P<0.01, * * P<0.05, * P<0.1$. 
effect of misalignment in some specifications is significantly positive when the ER is not fixed. ${ }^{27}$ This result is robust to estimation method: for the GDP price level all specifications confirm the negative effect of misalignment in countries with fixed ERs. For the internal relative price, the parameter of misalignment is also negative in all specifications, though not significant when misalignment is estimated with country fixed effect. Habib et al. (2017) also find that the growth effect of misalignment is stronger if the ER is pegged.

Next, we investigate whether the differences in patterns of misalignments, namely the magnitude and persistence might account for the observed differences in the growth effect of the misalignment between the alternative ER regimes. The effect of the ER regime on the average size and the persistence of the misalignment is not straightforward. On the one hand, under flexible ERs, price adjustments might materialize also through nominal ER changes that can promote cross country price convergence if nominal prices are stickier than the nominal ER. Under fixed ERs, in turn, in lack of nominal ER adjustment, misalignments might be more persistent and sizable. On the other hand, excessive nominal ER volatility might be a source of destabilizing shocks and may increase the volatility of the RER (e.g. Berka et al. 2012). Moreover, fixed ERs - by decreasing transaction costs - might enhance trade and hence induce crosscountry price convergence (e.g. Rose 2000).

In our sample, the average size and the standard deviation of misalignments are even smaller in the fixed ER countries (see Appendix, Table A13). The persistence of misalignments is measured similarly to Fidora et al. (2017), who measure it by the $\gamma$ parameter in regression (5), indicating the responsiveness of the RER to past misalignments. A negative parameter indicates mechanisms moving the RER toward the neutral level. The higher is the absolute value of the parameter, the lower is the persistence of the misalignment. The regression is similar to the short-term ECM equations, with the main difference that our regression captures long term, five-year changes in the ER.

$$
d R E R_{t / t-5, i}=\vartheta+\vartheta d G D P_{t / t-5, i}^{R E L}+\varphi M i s_{t-5, i}+\varepsilon_{i t}
$$

$d R E R_{t / t-5, i}$ and $G D P_{t / t-5, i}^{R E L}$, respectively, denote the change in the RER (based on the GDP price level and internal relative price) and variables of relative development (per capita or per worker GDP) compared to its's value five years earlier, and $\varphi M i s_{t-5, i}$ denotes the corresponding misalignment lagged with five years.

The estimated persistence exhibits a mixed picture (see Table 6). The GDP price level misalignments proved to be somewhat more persistent in the fixed ER countries, however, internal relative price misalignments show larger persistency for the floating countries, but the difference is not particularly sizable in either case. We get similar results if we estimate regression (5) with country fixed effect and investigate persistence for a shorter time span, three or four years.

4.3.2. Nonlinearity: the sign and size heterogeneity in the effect of RER misalignment. Many papers find that overvaluation hinders, while undervaluation enhances growth. Our baseline specification - where misalignment is represented with its sign - also implies that not only the

\footnotetext{
${ }^{27} \mathrm{We}$ also investigated whether the ER regime influences the long-term RER, but the dummy for fixed ER proved to be insignificant in all specifications for the long-term relationship.
} 
Table 6. Persistence of misalignment for fixed and floating exchange rate countries

\begin{tabular}{|c|c|c|c|c|c|c|c|c|}
\hline \multirow{4}{*}{$\begin{array}{l}\text { misalignment } \\
\text { d.RER (t/t-5) }\end{array}$} & (1) & (2) & (3) & (4) & (5) & (6) & (7) & (8) \\
\hline & \multicolumn{2}{|c|}{ mis_pl_vlc } & \multicolumn{2}{|c|}{ mis_pl_vlw } & \multicolumn{2}{|c|}{ mis_rp_vlc } & \multicolumn{2}{|c|}{ mis_rp_vlw } \\
\hline & \multicolumn{2}{|c|}{ S5.log_pl15_gdp } & \multicolumn{2}{|c|}{ S5.log_pl15_gdp } & \multicolumn{2}{|c|}{ S5.log_rp_s_g } & \multicolumn{2}{|c|}{ S5.log_rp_s_g } \\
\hline & Floating & fix & floating & fix & floating & fix & floating & fix \\
\hline \multirow[t]{2}{*}{ L5.misal } & $-0.362 * * *$ & $-0.243 * * *$ & $-0.275^{* * *}$ & $-0.212^{* * *}$ & $-0.146 * * *$ & $-0.220 * * *$ & $-0.131 * * *$ & $-0.159 * * *$ \\
\hline & $(0.053)$ & $(0.038)$ & $(0.053)$ & $(0.030)$ & $(0.044)$ & $(0.034)$ & $(0.041)$ & $(0.031)$ \\
\hline \multirow[t]{2}{*}{ log_vlc15_gdp(t/t-5) } & $0.561 * * *$ & $0.486 * * *$ & & & $0.272 * * *$ & $0.190 * * *$ & & \\
\hline & $(0.083)$ & $(0.033)$ & & & $(0.058)$ & $(0.029)$ & & \\
\hline \multirow[t]{2}{*}{ log_vlw15_gdp(t/t-5) } & & & $0.610 * * *$ & $0.592 * * *$ & & & $0.253^{* * *}$ & $0.298 * * *$ \\
\hline & & & $(0.084)$ & $(0.044)$ & & & $(0.059)$ & $(0.039)$ \\
\hline \multirow[t]{2}{*}{ Constant } & $0.023^{*}$ & $0.010 * * *$ & 0.012 & $0.008^{*}$ & -0.008 & 0.004 & -0.004 & 0.003 \\
\hline & $(0.012)$ & $(0.004)$ & $(0.013)$ & $(0.004)$ & $(0.009)$ & $(0.003)$ & $(0.009)$ & $(0.004)$ \\
\hline Controls & YES & YES & YES & YES & YES & YES & YES & YES \\
\hline Observations & 154 & 300 & 154 & 300 & 108 & 293 & 108 & 293 \\
\hline R-squared & 0.334 & 0.440 & 0.331 & 0.395 & 0.266 & 0.288 & 0.218 & 0.250 \\
\hline
\end{tabular}

Notes: Clustered standard errors in parentheses ${ }^{* * *} P<0.01,{ }^{*} P<0.05,{ }^{*} P<0.1$. 
distance, but also the sign of the deviation from the "neutral" level matters, that is, overvaluation effects growth in an opposite way as undervaluation. ${ }^{28}$ However, one might question whether the magnitude of the effect depends on the sign of the misalignment. One can assume that the effect of a change in the RER might be different if the RER is overvalued from the effect of a change in case of initial undervaluation. If prices and wages can be characterized by asymmetric downward rigidity, the adverse effect of overvaluation might be stronger than the favourable growth effect of the undervaluation. On the other hand, Rodrik (2008) found that for the developing countries, the positive effect of an increase of undervaluation is just as powerful as the negative growth effect of overvaluation.

In addition to the sign, the size of the misalignment might also influence the growth effect of misalignment. Bereau et al. (2012) find that the growth effect of the misalignment is not linear but increases with the size. Aquierre - Calderon (2005) investigated non-linearity separately for undervaluation and overvaluation and found that the size of the misalignment indeed matters, but while large overvaluations are excessively harmful, the positive effect of undervaluation loses momentum with increasing the magnitude and becomes negative above a certain level. Rodrik (2008) found little evidence of nonlinearity in the relationship between RER misalignment and economic growth.

We tested the sign and size asymmetries, adding overvaluation, undervaluation and the squared values of overvaluation and undervaluation separately. In case of undervaluation, the squared value is multiplied by minus one (Similar methodology was applied by Aquirre Calderon 2005). ${ }^{29}$

The added variables are the following:

$u_{-}$misal $_{i t}=D_{i t}{ }^{*}$ misal $_{i t}$ where $D_{i t}=1$, if the currency is undervalued and zero if overvalued. Consequently, $o_{-} m i s a l_{i t}=\left(1-D_{i t}\right) * m i s a l_{i t}$.

$s q_{-} u_{-} m i s a l_{i t}$ is the squared value of $u_{-} m i s a l_{i t}$, multiplied by -1 , and $s_{-} o_{-} m i s a l_{i t}$ is the square of $o_{-}$misal $_{i t}$.

Our results (Table 7) suggest that in the case of GDP price levels, moderate undervaluations are positively associated with growth, nevertheless, this diminishes with increasing magnitude, as the coefficient of the squared undervaluation is significantly positive. Similar nonlinearity was found in Aguirre - Calderon (2005). Consequently, a country cannot expect much gain from an excessively undervalued RER, and the parameter values imply that above 25-30 per cent the positive effect turns negative. This result is more in line with the so called "Washington Consensus" 30 which states that large misalignments imply significant distortions and imbalances that are harmful for growth in both directions; the result is also in line with Oblath et al. (2015). However, the significant coefficient of the square term might also be the consequence of the coincidence of economic and currency crises, rather than the harmful effect of large undervaluations. Misaligned internal relative prices do not show this type of asymmetry. Both the values and the squared value of overvaluation lose significance in this specification, and the

\footnotetext{
${ }^{28}$ If only the absolute size of misalignments was considered, it would not be possible to differentiate between the effects of over- and undervaluations.

${ }^{29}$ First we tested the sign asymmetry by adding the dummy variable $D_{i t}$ and the interaction term of the dummy variable $u_{-}$misal $_{i t}$ to the baseline regression, however, the interaction term was not significant in any specifications.

${ }^{30}$ See e.g., Edwards (1998) and Berg - Miao (2010).
} 
Table 7. Testing for nonlinear effects. Dependent variable: annual growth rate of GDP per capita volume (dlog_qc_gdp)

\begin{tabular}{|c|c|c|c|c|c|c|c|c|}
\hline & (1) & (2) & (3) & (4) & (5) & (6) & (7) & (8) \\
\hline & \multicolumn{4}{|c|}{ GDP price level } & \multicolumn{4}{|c|}{ Internal relative price } \\
\hline & $\begin{array}{l}\text { Lagged } \\
\text { dep.var. }\end{array}$ & $\begin{array}{l}\text { Fixed } \\
\text { effect }\end{array}$ & $\begin{array}{l}\text { System } \\
\text { GMM }\end{array}$ & $\begin{array}{l}\text { Lagged misal, lagged } \\
\text { dep var }\end{array}$ & $\begin{array}{c}\text { Lagged } \\
\text { dependent var }\end{array}$ & $\begin{array}{l}\text { Fixed } \\
\text { effect }\end{array}$ & $\begin{array}{l}\text { System } \\
\text { GMM }\end{array}$ & $\begin{array}{l}\text { Lagged misal, lagged } \\
\text { dep var }\end{array}$ \\
\hline \multirow[t]{2}{*}{ undervalued } & 0.001 & -0.003 & 0.006 & & -0.002 & -0.002 & 0.001 & \\
\hline & $(0.005)$ & $(0.005)$ & $(0.007)$ & & $(0.004)$ & $(0.005)$ & $(0.005)$ & \\
\hline \multirow[t]{2}{*}{ umisal } & $-0.109 * *$ & $-0.314 * * *$ & -0.111 & & -0.028 & -0.119 & -0.027 & \\
\hline & $(0.048)$ & $(0.072)$ & $(0.073)$ & & $(0.044)$ & $(0.083)$ & $(0.058)$ & \\
\hline \multirow[t]{2}{*}{ o_misal } & 0.000 & $-0.127^{*}$ & 0.062 & & -0.079 & $-0.159 *$ & -0.091 & \\
\hline & $(0.054)$ & $(0.074)$ & $(0.083)$ & & $(0.052)$ & $(0.082)$ & $(0.077)$ & \\
\hline \multirow[t]{2}{*}{ misal_sq_u } & $0.399 * *$ & $1.009 * * *$ & 0.314 & & 0.013 & 0.211 & -0.012 & \\
\hline & $(0.163)$ & $(0.198)$ & $(0.227)$ & & $(0.103)$ & $(0.191)$ & $(0.146)$ & \\
\hline \multirow[t]{2}{*}{ misal_sq_o } & -0.060 & 0.123 & -0.179 & & $0.283 * *$ & 0.253 & $0.436 * *$ & \\
\hline & $(0.147)$ & $(0.169)$ & $(0.224)$ & & $(0.128)$ & $(0.197)$ & $(0.175)$ & \\
\hline \multirow[t]{2}{*}{ L.under } & & & & $-0.010 *$ & & & & -0.001 \\
\hline & & & & $(0.005)$ & & & & $(0.004)$ \\
\hline \multirow[t]{2}{*}{ L.u_misal } & & & & $-0.173 * * *$ & & & & -0.040 \\
\hline & & & & $(0.051)$ & & & & $(0.032)$ \\
\hline \multirow[t]{2}{*}{ L.o_misal } & & & & -0.036 & & & & -0.043 \\
\hline & & & & $(0.042)$ & & & & $(0.056)$ \\
\hline \multirow[t]{2}{*}{ L.misal_sq_u } & & & & $0.542 * * *$ & & & & 0.069 \\
\hline & & & & $(0.161)$ & & & & $(0.081)$ \\
\hline
\end{tabular}


Table 7. Continued

\begin{tabular}{|c|c|c|c|c|c|c|c|c|}
\hline & (1) & (2) & (3) & (4) & (5) & (6) & (7) & (8) \\
\hline & \multicolumn{4}{|c|}{ GDP price level } & \multicolumn{4}{|c|}{ Internal relative price } \\
\hline & $\begin{array}{l}\text { Lagged } \\
\text { dep.var. }\end{array}$ & $\begin{array}{l}\text { Fixed } \\
\text { effect }\end{array}$ & $\begin{array}{l}\text { System } \\
\text { GMM }\end{array}$ & $\begin{array}{l}\text { Lagged misal, lagged } \\
\text { dep var }\end{array}$ & $\begin{array}{l}\text { Lagged } \\
\text { dependent var }\end{array}$ & $\begin{array}{l}\text { Fixed } \\
\text { effect }\end{array}$ & $\begin{array}{l}\text { System } \\
\text { GMM }\end{array}$ & $\begin{array}{l}\text { Lagged misal, lagged } \\
\text { dep var }\end{array}$ \\
\hline \multirow[t]{2}{*}{ L.misal_sq_o } & & & & 0.076 & & & & 0.228 \\
\hline & & & & $(0.111)$ & & & & $(0.170)$ \\
\hline Controls & YES & YES & YES & YES & YES & YES & YES & YES \\
\hline Observations & 538 & 564 & 511 & 538 & 508 & 522 & 494 & 495 \\
\hline R-squared & 0.687 & 0.636 & & 0.684 & 0.699 & 0.641 & & 0.730 \\
\hline
\end{tabular}

Notes: Clustered standard errors in parentheses ${ }^{* * *} P<0.01,{ }^{* *} P<0.05,{ }^{*} P<0.1$. 
overvaluation shows diminishing negative effect. One explanation might be that while the level of misaligned internal relative prices has significant negative effect, the threshold between under- and overvaluation is not estimated precisely.

4.3.3. Asymmetry with respect to the CEEU countries. A common finding in the literature is that in the highly developed countries growth is less affected by RER misalignment (e.g. McDonald - Vieira 2010) or is completely unaffected (Rodrik 2008). Rodrik (2008) argued that bad institutions and market failures have a much stronger impact on the tradable sector than on the non-tradables. Since in the developing countries these problems are probably more serious, suboptimal amount of resources will be used in the tradable sector. RER undervaluation makes the production of tradables more profitable; thus, it pushes the economy closer to the optimal level of production. He empirically tested this hypothesis and found that the effect of RER misalignment on growth proved to be larger for the economies with bad institutions.

Estimations of Rodrik (2008) and McDonald - Vieira (2010) are based on a mixed sample of developed and developing countries. The EU is more homogenous in terms of GDP per capita than the above samples, however, the differences in the stage of development also play a role within the EU. We investigate whether an asymmetry exists between the developed EU countries and the newcomer CEEU countries. Despite the substantial convergence of the CEEU countries, the group as a whole lags behind in terms of GDP per capita throughout the period (see Appendix, Table A14). Beyond the lag in the level of development, the CEEU countries might behave differently because of the structural differences inherited from the socialist era.

The asymmetry is tested by adding the interaction term of misalignment and the dummy variable for the CEEU countries to our basic regression. The results are mixed across growth and misalignment measurements and show asymmetry only for the GDP price level misalignments. As Table 8 shows, the cross-term is insignificant in the case of misalignment in internal relative prices, and insignificant, or significantly positive in some specifications of the GDP price based misalignment, implying that the relationship with misalignments is similar or weaker than in the non-CEEU-countries.

The important takeaway from this table is that within the EU, the less developed countries do not react more strongly to ER misalignments, that is, our results do not confirm the usual finding in the literature that misaligned RERs have stronger growth effects in the countries with lower GDP per capita. However, the estimated misalignments might largely differ depending on the pool of countries included in the estimation sample, even if estimated with the same method. As already discussed in Section 3, the misalignments which are estimated on the sample of the EU countries differ significantly from the misalignments that are based on a broader sample of 146 developing and developed countries of the PWT. Besides, one has to note that while the majority of the developed EU countries (except UK and Sweden) have been operating under a fixed ER regime since 1997, the CEEU countries exhibit more heterogeneous picture regarding the ER regime. ${ }^{31}$

\footnotetext{
${ }^{31}$ Since 1995, the following CEEU countries operated under the fixed ER regime: BU, EE, LT, LV; since 2007: SI; since 2009: SK. Table A16 in the Appendix includes the classification of the EU member-states by the ER regimes.
} 
Table 8. Estimates for asymmetric effect on the CEEU countries. Dependent variable: annual growth rate of GDP per capita volume (qc_gdp)

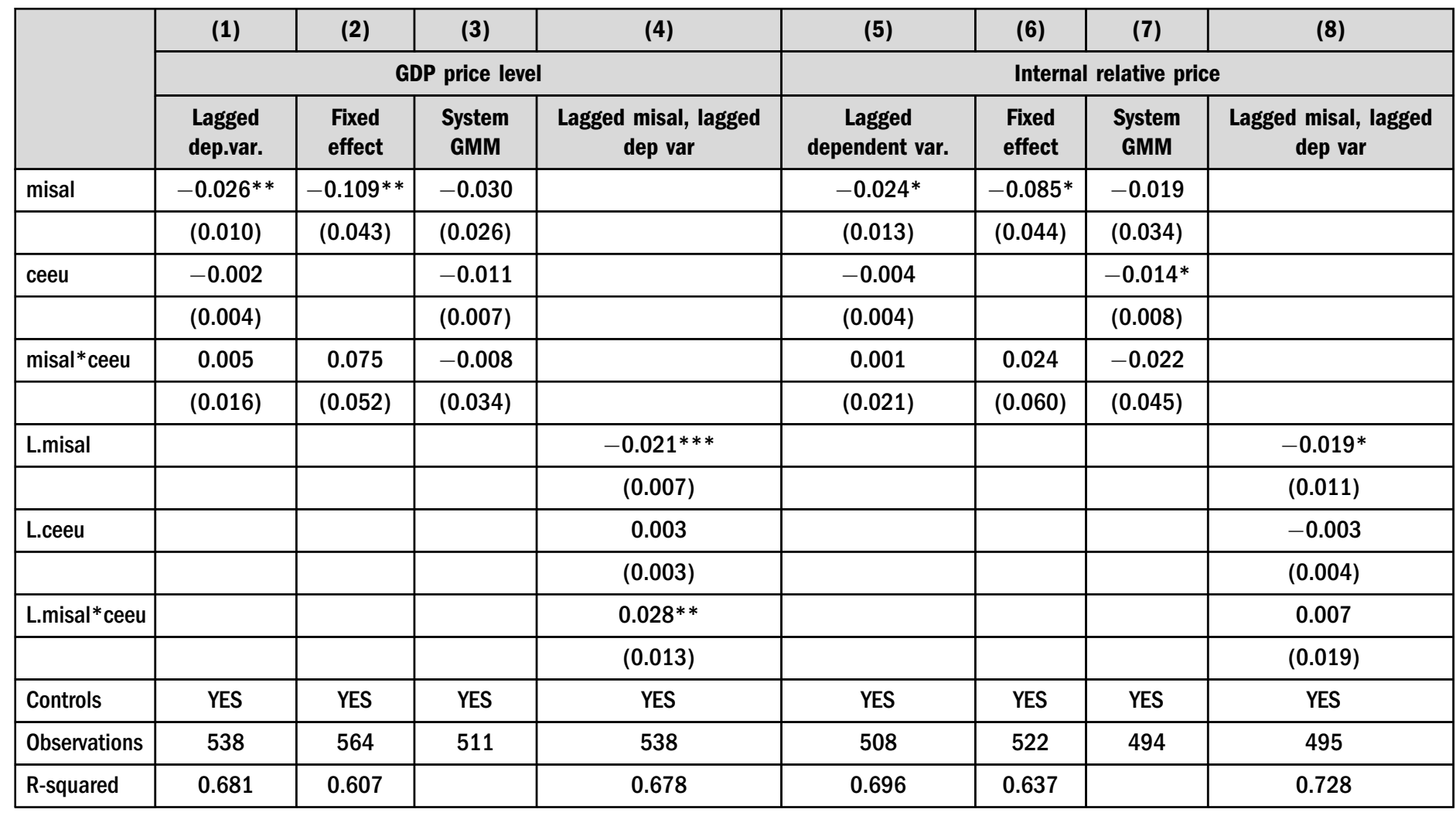

Notes: Clustered standard errors in parentheses ${ }^{* * *} P<0.01,{ }^{* *} P<0.05,{ }^{*} P<0.1$. 


\subsection{Channels: investment and competitiveness}

From a policy point of view, a key question regarding the connection between growth effect and RER misalignment is the transmission channel through which misalignment exerts its effect on growth. There are three main channels identified by the literature. These point to a symmetric effect in the sense that undervaluation enhances and overvaluation hinders growth, i.e., the direction of the deviation from the value implied by the fundamentals have a great importance.

The conventional competitiveness channel (e.g. Obstfeld - Rogoff 1996) argues that a more undervalued RER increases the profitability of the export sector and enhances growth through conjuncture in exports, while the increase in the price of imports increases the growth via the expenditure switching mechanism.

Table 9. Effect of RER misalignment level on private investment/GDP. Dependent variable: Private investments/GDP

\begin{tabular}{|c|c|c|c|c|c|c|}
\hline & (1) & (2) & (3) & (1) & (2) & (3) \\
\hline & $\begin{array}{l}\text { Lagged } \\
\text { dependent } \\
\text { var. }\end{array}$ & $\begin{array}{l}\text { System } \\
\text { GMM }\end{array}$ & $\begin{array}{l}\text { Lagged misal, } \\
\text { lagged } \\
\text { dependent var. }\end{array}$ & $\begin{array}{l}\text { Lagged } \\
\text { dependent } \\
\text { var. }\end{array}$ & $\begin{array}{c}\text { System } \\
\text { GMM }\end{array}$ & $\begin{array}{l}\text { Lagged misal, } \\
\text { lagged } \\
\text { dependent var. }\end{array}$ \\
\hline & \multicolumn{3}{|c|}{ GDP price level } & \multicolumn{3}{|c|}{ Internal relative price } \\
\hline \multirow{2}{*}{ L.inv_gdp } & $0.815^{* * *}$ & $1.110 * * *$ & $0.816 * * *$ & $0.839 * * *$ & $1.135^{* * *}$ & $0.840 * * *$ \\
\hline & $(0.044)$ & $(0.084)$ & $(0.043)$ & $(0.050)$ & $(0.056)$ & $(0.052)$ \\
\hline \multirow[t]{2}{*}{ Misal } & $-0.020 * *$ & $-0.026 * * *$ & & $-0.029 *$ & $-0.048 * * *$ & \\
\hline & $(0.007)$ & $(0.010)$ & & $(0.015)$ & $(0.017)$ & \\
\hline \multirow[t]{2}{*}{ L.misal } & & & $-0.020 * *$ & & & $-0.032 *$ \\
\hline & & & $(0.007)$ & & & $(0.015)$ \\
\hline \multirow[t]{2}{*}{ log_vlc15_gdp_i5 } & $-0.006 * *$ & $-0.007 * * *$ & $-0.006 * *$ & -0.002 & $-0.004 * * *$ & $-0.005^{* *}$ \\
\hline & $(0.002)$ & $(0.001)$ & $(0.002)$ & $(0.004)$ & $(0.001)$ & $(0.002)$ \\
\hline \multirow[t]{2}{*}{ Free } & 0.059 & $0.046^{*}$ & 0.061 & 0.039 & $0.042 *$ & $0.051 *$ \\
\hline & $(0.035)$ & $(0.028)$ & $(0.036)$ & $(0.024)$ & $(0.022)$ & $(0.027)$ \\
\hline \multirow[t]{2}{*}{ tot_eff } & 0.038 & $-0.226 *$ & 0.039 & 0.061 & -0.170 & 0.002 \\
\hline & $(0.131)$ & $(0.126)$ & $(0.132)$ & $(0.235)$ & $(0.171)$ & $(0.198)$ \\
\hline \multirow[t]{2}{*}{ Constant } & -0.010 & $0.267^{* *}$ & -0.013 & -0.043 & 0.201 & 0.021 \\
\hline & $(0.137)$ & $(0.135)$ & $(0.138)$ & $(0.248)$ & $(0.178)$ & $(0.204)$ \\
\hline Observations & 251 & 240 & 251 & 240 & 232 & 236 \\
\hline R-squared & 0.888 & & 0.888 & 0.879 & $1.135 * * *$ & 0.885 \\
\hline
\end{tabular}

Notes: Clustered standard errors in parentheses $* * * P<0.01,{ }^{* *} P<0.05, * P<0.1$. 
The other main channel emphasizes the role of capital accumulation. Rodrik (2008) argues that an undervalued RER enhances investment and production in the tradable sector, but only in the developing countries, where bad institutions and market failure lead to a suboptimal share of the tradable sector, which suffers more from the institutional weakness. Other papers emphasize the positive effect of RER undervaluation on overall savings and investments, implying that the beneficial impact on investment is not limited to the tradable sector (e.g. Bhalla 2012).

A related mechanism, the total factor productivity channel (e.g. Mbaye 2013) also considers increased profitability of the tradable sector as a starting point, but the focus is rather on compositional changes in the economy. Namely, production shifts from the low-productivity non-tradable sector towards the more productive tradable sector, are ultimately increasing the overall productivity of the economy.

In the following, we try to identify the importance of the competitiveness and the investment channels by applying the investment to GDP ratio and the change in export market share at

Table 10. Effect of RER misalignment on export market share. Dependent variable: export market share

\begin{tabular}{|c|c|c|c|c|c|c|}
\hline & (1) & (2) & (3) & (1) & (2) & (3) \\
\hline & $\begin{array}{c}\text { Lagged } \\
\text { dependent } \\
\text { var. }\end{array}$ & $\begin{array}{l}\text { System } \\
\text { GMM }\end{array}$ & $\begin{array}{l}\text { Lagged misal, } \\
\text { lagged } \\
\text { dependent var. }\end{array}$ & $\begin{array}{c}\text { Lagged } \\
\text { dependent } \\
\text { var. }\end{array}$ & $\begin{array}{l}\text { System } \\
\text { GMM }\end{array}$ & $\begin{array}{l}\text { Lagged misal, } \\
\text { lagged } \\
\text { dependent var. }\end{array}$ \\
\hline & \multicolumn{3}{|c|}{ GDP price level } & \multicolumn{3}{|c|}{ Internal relative price } \\
\hline \multirow[t]{2}{*}{ L.dlog_xcomp2 } & $0.232 * * *$ & $0.225^{* * *}$ & $0.236 * * *$ & $0.237 * * *$ & $0.224 * * *$ & $0.214^{* * *}$ \\
\hline & $(0.047)$ & $(0.080)$ & $(0.046)$ & $(0.056)$ & $(0.084)$ & $(0.051)$ \\
\hline \multirow[t]{2}{*}{ misal } & $-0.041 * * *$ & $-0.041 * *$ & & $-0.052 * * *$ & $-0.060 * * *$ & \\
\hline & $(0.013)$ & $(0.020)$ & & $(0.015)$ & $(0.023)$ & \\
\hline \multirow[t]{2}{*}{ L.misal } & & & $-0.028 *$ & & & $-0.039 * * *$ \\
\hline & & & $(0.015)$ & & & $(0.012)$ \\
\hline \multirow[t]{2}{*}{ log_vlc15_gdp_i5 } & $-0.028 * * *$ & $-0.040 * * *$ & $-0.028 * * *$ & $-0.030 * * *$ & $-0.033 * * *$ & $-0.039 * * *$ \\
\hline & $(0.006)$ & $(0.008)$ & $(0.006)$ & $(0.007)$ & $(0.007)$ & $(0.006)$ \\
\hline \multirow[t]{2}{*}{ free } & $0.114^{* *}$ & $0.169 * *$ & $0.109 * *$ & $0.072^{*}$ & $0.143^{* *}$ & $0.093 * *$ \\
\hline & $(0.047)$ & $(0.085)$ & $(0.046)$ & $(0.036)$ & $(0.063)$ & $(0.039)$ \\
\hline \multirow[t]{2}{*}{ tot_eff } & $-1.339 * * *$ & $-1.703 * * *$ & $-1.354 * * *$ & $-1.582 * * *$ & $-1.573 * * *$ & $-1.314^{* * *}$ \\
\hline & $(0.465)$ & $(0.596)$ & $(0.466)$ & $(0.509)$ & $(0.498)$ & $(0.457)$ \\
\hline \multirow[t]{2}{*}{ Constant } & $1.397 * * *$ & $1.768 * * *$ & $1.414 * * *$ & $1.684 * * *$ & $1.628 * * *$ & $1.445^{* * *}$ \\
\hline & $(0.459)$ & $(0.597)$ & $(0.460)$ & $(0.524)$ & $(0.501)$ & $(0.467)$ \\
\hline Observations & 534 & 534 & 534 & 506 & 506 & 494 \\
\hline R-squared & 0.263 & & 0.257 & 0.285 & & 0.272 \\
\hline
\end{tabular}

Notes: Clustered standard errors in parentheses ${ }^{* * *} P<0.01,{ }^{* *} P<0.05,{ }^{*} P<0.1$. 
international markets as dependent variables instead of GDP growth. Specifically, we estimate Eq. (1) using an indicator of investment and that of competitiveness as the dependent variable and modify the set of control variables.

The variables are the following:

dlog_ms: the competitiveness channel is investigated by an indicator expressing market performance of exports of goods and services on export weighted imports of goods and services: 36 industrial markets $2010=100$ (AMECO). The variable is represented in dlog form.

inv: the investment channel is represented by private gross capital formation as percent of GDP.

Our results (Tables 9 and 10) suggest that both the competitiveness and the investment channels play a role in the effect of RER misalignment. The misalignment is negatively associated with both changes in export market shares and the private investment/GDP ratio; the results are similar for misalignment in the GDP price level and the internal relative price. Regarding private investment/GDP, the results are similar, though the parameter of misalignment is not significant at $5 \%$ significance level in all specifications. The index of economic freedom affects the change in market share positively in all specifications. It is worth noting that the effect of the terms of trade differs for competitiveness and investment. An increase in the terms of trade worsens export performance, that is, higher relative export prices are accompanied by lower quantities. However, changes in the terms of trade have no significant effect on the investment/GDP ratio.

It is to be noted that our results do not imply that we rule out the operation of the channel involving total factor productivity. However, since it is not straightforward to empirically disentangle the increase in capital/labour ratio from that in total factor productivity, we cannot draw conclusions on the existence of this mechanism.

\section{THE EFFECT OF MISALIGNMENTS BASED ON THE RELATIONSHIP BETWEEN WAGE AND PRODUCTIVITY LEVELS: AN EXTENSION (ONLINE)}

\section{SUMMARY AND CONCLUSIONS}

The main goals of our study were to investigate (i) the characteristics of real economic and price convergence, (ii) the relationship between economic growth (convergence) and RER misalignments within the EU during the period of 1995-2016. Although this relationship has been analysed by several studies with respect to the global economy (i.e., relying on samples consisting of countries at markedly different levels of development), little attention has been devoted to investigating this association among member-states of the EU.

We rely on the observation that within the EU there is a very close positive correlation between general price levels on the one hand, and levels of economic development, on the other. While the existence of this relationship - the so-called "Penn-effect" - is a worldwide phenomenon, it holds much more strongly within the EU. This implies that economic integration through trade, capital and labour flows does not lead to the equalisation of price levels among 
countries at different levels of development; rather it results in an exceptionally close positive association between levels of prices and economic development.

Our interpretation and quantitative estimations of RER misalignments build upon this close association: we consider national RERs to be misaligned, if GDP price levels deviate from the level characterising the relationship between price levels and real incomes (measured by per capita or per employed GDP at PPP) for the EU as a whole. We refer to the points corresponding to the common trend as expressing a "neutral" RER; national price levels above (below) the neutral one were interpreted as signs of RER-over- (under-) valuation. In this respect, we followed the approach of previous studies on the topic.

However, as an important conceptual and empirical contribution to the literature on RER misalignments and economic growth, in addition to the relative price level of GDP, we quantified an alternative indicator for the RER: the internal relative price of services to goods, as measured from the expenditure side of GDP. This indicator is also closely correlated with the level of economic development and can be regarded as a measure of the "internal" RER (i.e., as a proxy for the relative price of non-tradables to tradables.) We estimated RER-misalignments (with and without controlling for openness and the relative size of government expenditure) relying on this concept as well.

The core of our analyses involves estimation results regarding the relationship between economic growth and RER-misalignments within the EU. We finally applied four indicators for quantifying misalignments (two based on the relative price of GDP and two on the internal relative price) and eight different specifications.

Our results indicate that the contemporaneous extent of RER misalignment - as interpreted by the relative price of GDP - is negatively associated with economic growth: a $10 \%$ over/undervaluation is accompanied by $0.2-0.7$ percentage point lower/higher rate of growth across different specifications in the EU. This effect is substantial, considering the fact that the mean annual growth rate of GDP (per capita GDP) was 2.4\% (2.3\%) in the EU27 over the period covered by our analysis. The relationship between growth and misalignments based on internal RERs in some cases holds even more than those based on GDP price levels, highlighting the role of relative prices in resource allocation. A robust finding of the study is that the negative association between growth and RER-misalignments is mainly attributable to the countries operating under the fixed ER regimes, that is, to the Eurozone countries and the CEEU countries with pegged ERs or currency-board arrangements. This finding is robust to the choice of growth indicator, the measure of relative level of development and the interpretation of the RER.

Our results show that, in contrast with the common finding in the literature, the level of development does not influence the strength of the relationship between misalignments and economic growth. While the GDP price level-based and internal relative price-based misalignments behave similarly on the aggregate sample, our findings are mixed regarding the symmetry with respect to the size and sign of the misalignment. Specifically, in the case of the GDP price level, overvaluation has stronger effect than undervaluation, and while larger overvaluations have an excessively negative growth effect, the positive effect of undervaluation diminishes with increasing its magnitude. The growth effect of internal relative price misalignment does not show this pattern.

Some of our main findings are robust to the applied panel econometric method. In addition to time fixed effect specifications, we carried out system and difference GMM methods, specifying the misalignment as an endogenous variable, hence addressing the potential endogeneity 
bias. The GMM estimations confirm the negative relationship between misalignments in the case of the GDP price level for the fixed ER countries. GMM specifications do not show significant asymmetry for the CEEU countries and show that the positive undervaluation-growth relationship diminishes with increasing the magnitude of undervaluation.

We addressed two possible channels through which RER misalignments might influence economic growth: international competitiveness and the investment rate. The aggregate effect of misalignments is significantly negative on both export market shares and the ratio of private gross fixed capital formation to GDP, although the results for investments are less stable. This result indicates that both the competitiveness and, to some extent, the investment channel play a role in the growth effect of the RER misalignments.

As an extension, we analysed the relationship between growth and the misalignment of wages from productivity levels and found that "wage-misalignments" are also negatively associated with economic growth.

Our results capture contemporaneous and one-year lagged effects of RER misalignments, which are highly relevant for understanding growth and convergence in the EU member-states in certain sub-periods of the 21 years covered by our study, but these results do not enable us to draw conclusions regarding the long-term effects of misaligned price levels and relative prices.

It is also important to stress that although our study carries important policy messages - in particular, mild RER undervaluations are positively, while overvaluations are negatively associated with growth and real economic convergence - the RER is an endogenous variable, which is not under direct policy control. However, there are several policy instruments for indirectly influencing the RER, even in the countries operating under fixed ER. Our results point to the importance of a growth strategy avoiding overvaluation on the one hand, and to the futility of aiming at excessive undervaluation, on the other. Rather than trying to achieve an undervalued RER, governments are advised to focus on improving the quality of institutions.

We consider the results presented in this paper as a first step in our attempt to clarify the relationship between RER-misalignments and economic growth within the EU. As a next step, it is important to build a theoretical model capable of reproducing the empirical results reported in our study. As a continuation of our work, we also wish to address issues left open in the present study. Two, as yet unexplained, phenomena require further analysis: (i) why does the relationship between misalignments and growth hold only for the countries with fixed ER; (ii) why only misalignments based on internal relative prices "work" in the case of the CEEU countries? Furthermore, the general results of our study need to be amended by the analysis of individual country-experiences with respect to the evolution of the RER and economic convergence.

\section{ACKNOWLEDGEMENTS}

The research was supported by the Hungarian National Research, Development and Innovation Office, project No. K-124808. The authors acknowledge the helpful comments of László Halpern, István Kónya, Róbert Lieli, Gábor Pintér and Károly Attila Soós on earlier drafts. Any remaining errors are those of the authors. 


\section{REFERENCES ${ }^{32}$}

Acemoglu, D. - Johnson, S. - Thaicharoen, Y. - Robinson, J. (2002): Institutional Causes, Macroeconomic Symptoms: Volatility, Crisis and Growth. NBER Working Paper, No. 9124.

Aguirre, A. - Calderon, C. (2005): Real Exchange Rate Misalignments and Economic Performance. Central Bank of Chile, Working Paper, No. 315.

Andersson, M. - Masuch, K. - Schiffbauer, M. (2009): Determinants of Inflation and Price Level Differentials across the Euro Area Countries. European Central Bank, Working Paper Series, No. 1129.

Angrist, J. - Pischke, J. S. (2009): Mostly Harmless Econometrics: An Empiricist's Companion. Princeton: Princeton University Press.

Asea, P. K. - Corden, W. M. (1994): The Balassa-Samuelson Model: An Overview. Review of International Economics, 2(3): 191-200.

Atkinson, A. B. (2015): Inequality: What can be Done? Harvard University Press.

Balassa, B. (1964): The Purchasing Power Doctrine: A Reappraisal. Journal of Political Economy, 72(6): 584-596. Benaroya, F. - Janci, D. (1999): Measuring Exchange Rates Misalignments with Purchasing Power Parity Estimates. In: Collignon, S. - Pisani-Ferry, J. - Park, Y. C. (eds): Exchange Rate Policies in Emerging Asian Countries. New York: Routledge, pp. 222-242.

Bereau, S. - Lopez-Villavicencio, A. - Mignon, V. (2012): Currency Misalignments and Growth: A New Look Using Nonlinear Panel Data Methods. Applied Economics, 44(27): 3503-3511.

Berg, A. - Miao, Y. (2010): The Real Exchange Rate and Growth Revisited: The Washington Consensus Strikes Back? IMF Working Papers, No. 10/58.

Bergstrand, J. H. (1991): Structural Determinants of Real Exchange Rates and National Price Levels: Some Empirical Evidence. American Economic Review, 81(1): 325-334.

Berka, M. - Devereux, M. B. (2013): Trends in European Real Exchange Rates. Economic Policy, 28(74): 193-242.

Berka, M. - Devereux, M. B. - Engel, C. (2012): Real Exchange Rate Adjustment in and out of the Eurozone. American Economic Review, 102(3): 179-185.

Bhagwati, J. N. (1984): Why are Services Cheaper in the Poor Countries? Economic Journal, 94(374): 279-286.

Bhalla, S. S. (2012): Devaluing to Prosperity: Misaligned Currencies and Their Growth Consequence. Washington, DC: Peterson Institute for International Economics.

Blundell, R. - Bond, S. (1998): Initial Conditions and Moment Restrictions in Dynamic Panel Data Models. Journal of Econometrics, 87(1): 115-143.

Cassel, G. (1922): Money and Foreign Exchange after 1914. New York: Constable and Co.

Cavallo, D. F. - Cottani, J. A. - Kahn, M. S. (1990): Real Exchange Rate Behavior and Economic Performance in LDCS. Economic Development and Cultural Change, 39(1): 61-76.

Charpe, M. - Bridji, S. - McAdam, P. (2019): Labor Share and Growth in the Long Run. Macroeconomic Dynamics: $1-38$.

Clark, C. (1940): The Condition of Economic Progress. London: Mc Millan.

Clark, P. B. - MacDonald, R. (1999): Exchange Rates and Economic Fundamentals: A Methodological Comparison of BEERs and FEERs. In: MacDonald, R. - Stein, J. (eds): Equilibrium Exchange Rates. Kluwer Academic Publishers, pp. 285-322.

Corden, W. M. (1984): Booming Sector and Dutch Disease Economics: Survey and Consolidation. Oxford Economic Papers, 36(3): 359-380.

\footnotetext{
${ }^{32}$ References include studies referred to Section 5, accessible online.
} 
Cuestas, J. C. - Mourelle, E. - Regis, P. J. (2019): Real Exchange Rate Misalignments in CEECs: Have they Hindered Growth? Springer.

Devereux, M. B. (2014): Real Exchange Rates and the Balassa-Samuelson Effect Revisited. Research Summary. NBER Reporter, No. 4.

Dollar, D. (1992): Outward-Oriented Developing Economies Really Do Grow More Rapidly: Evidence from 95 LDCs, 1976-1985. Economic Development and Cultural Change, 40(3): 523-544.

Easterly, W. (2001): The Lost Decades: Developing Countries' Stagnation in Spite of Policy Reform 19801998. Journal of Economic Growth, 6(2): 135-157.

Edwards, S. (1998): Capital Flows, Real Exchange Rates, and Capital Controls: Some Latin American Experiences. NBER Working Paper, No. 6800.

Égert, B. (2010): Catching-up and Inflation in Europe: Balassa-Samuelson, Engel's Law and Other Culprits. OECD Economics Department Working Papers, No. 792.

Égert, B. - Halpern, L. - MacDonald, R. (2006): Equilibrium Exchange Rates in Transition Economies: Taking Stock of the Issues. Journal of Economic Surveys, 20(2): 257-324.

Eichengreen, B. (2008): The Real Exchange Rate and Economic Growth. Commission on Growth and Development Working Paper, No. 4. Washington, DC: World Bank.

Fajnzylber, P. R. - Loayza, N. - Calderon, C. (2002): Economic Growth in Latin America and the Caribbean. Washington, DC: World Bank.

Feenstra, R. C. - Inclaar, R. - Timmer, M. P. (2015): The Next Generation of the Penn World Tables. American Economic Review, 105(10): 3150-3182.

Fidora, M. - Giordano, C. - Schmitz, M. (2017): Real Exchange Rate Misalignments in the Euro Area. European Central Bank Working Paper Series, No. 2108.

Fischer, C. (2007): An Assessment of the Trends in International Price Competitiveness among EMU Countries. Deutsche Bundesbank Discussion Paper Series 1: Economic Studies, No. 08/2007.

Fourastié, J. (1950): La Grand Espoir du XX. Siecle. Paris: Presses Universitaires de France.

Galla, P. (2008): Real Exchange Rate Levels and Economic Development: Theoretical Analysis and Econometric Evidence. Cambridge Journal of Economics, 32(2): 273-278.

Galstyan, V. - Lane, P. R. (2009): The Composition of Government Spending and the Real Exchange Rate. Journal of Money, Credit and Banking, 41(6): 1233-1249.

Gubler, M. - Sax, Ch. (2019), The Balassa-Samuelson Effect Reversed: New Evidence from OECD Countries. Swiss Journal of Economics and Statistics, 155(1): 1-21.

Habib, M. M. - Mileva, E. - Stracca, L. (2017): The Real Exchange Rate and Economic Growth: Revisiting the Case Using External Instruments. Journal of International Money and Finance, 73(PB): 386-398.

Harrod, R. (1933): International Economics. London: Cambridge University Press.

Hassan, F. (2016): The Price of Development: The Penn-Balassa-Samuelson Effect Revisited. Journal of International Economics, 102(C): 291-309.

Isard, P. (2007), Equilibrium Exchange Rates; Assessment Methodologies. IMF Working Papers, No. 07/296. Johnson, S. - Ostry, J. D. - Subramanian, A. (2007): The Prospects for Sustained Growth in Africa: Benchmarking the Constraints. NBER Working Paper, No. 13120.

Kaldor, N. (1961): Capital Accumulation and Economic Growth. In: Lutz, F. A. - Hague, D. C. (eds): The Theory of Capital. Palgrave Macmillan, pp.177-222.

Kaldor, N. (1966): Causes of the Slow Rate of Growth of the United Kingdom: An Inaugural Lecture. Cambridge: Cambridge University Press.

Kaldor, N. (1971): Conflicts in National Economic Objectives. Economic Journal, 81(321): 1-16. 
Konya, I. - Kreko, J. - Oblath, G. (2020): Labor shares in the old and new EU member states - Sectoral effects and the role of relative prices. Economic. Modelling 90: 254-274.

Kravis, I. B. - Lipsey, R. (1983): Toward an Explanation of National Price Levels. Princeton Studies in International Finance, No. 52, November.

Kreko, J. - Oblath, G. (2018): Economic Convergence and Exchange Rate Misalignments in the European Union. MTA KRTK KTI Discussion Papers, No. 2018/25.

Kuznets, S. (1971): Economic Growth of Nations. Total Output and Production Structure. Massachusetts: Harvard University Press.

MacDonald, R. - Vieira, F. (2010): A Panel Data Investigation of Real Exchange Rate Misalignment and Growth. Cesifo Working Paper, No. 3061.

Mbaye, S. (2013): Currency Undervaluation and Growth: Is There a Productivity Channel? International Economics, 133: 8-28.

Oblath, G. - Palócz, É. - Popper, D. - Valentinyi, Á. (2015): Economic Convergence and Structural Change in the New Member States of the European Union. MTA KTI Discussion Papers, No. 2015/44.

Obstfeld, M. - Rogoff, K. (1996): Foundations of International Macroeconomics. Cambridge, MA: MIT Press.

Podkaminer, L. (2010): Real Convergence and Price Levels: Long-Term Tendencies Versus Short-Term Performance in the Enlarged European Union. Metroeconomica, 61(4): 640-664.

Podkaminer, L. (2011): Why Are Goods Cheaper in Rich Countries? Beyond the Balassa-Samuelson. Metroeconomica, 62(4): 712-728.

Podkaminer, L. (2017): Labour Productivity Growth Slowdown: An Effect of Economic Stagnation rather than its Cause? Acta Oeconomica, 67(S): 67-77.

Prasad, E. S. - Rajan, R. G. - Subramanian, A. (2007): Foreign Capital and Economic Growth. NBER Working Paper, No. 13619.

PWT (2017): Penn World Table version 9.0. The Database. https://www.rug.nl/ggdc/productivity/pwt/.

Razin, O. - Collins, S. M. (1997): Real Exchange Rate Misalignments and Growth. NBER Working Paper, No. 6174.

Razmi, A. - Rapetti, M. - Skott, P. (2012): The Real Exchange Rate and Economic Development. Structural Change and Economic Dynamics, 23(2): 151-169.

Rodrik, D. (2008): The Real Exchange Rate and Economic Growth. Brookings Papers on Economic Activity, 2: $365-412$.

Rogoff, K. (1996): The Purchasing Power Parity Puzzle. Journal of Economic Literature, 34(2): 647-668.

Rose, A. K. (2000): One Money, One Market: The Effect of Common Currencies on Trade. Economic Policy, 15(30): 7-33.

Samuelson, P. (1964): Theoretical Notes on Trade Problems. Review of Economics and Statistics, 46(2): 145-154.

Samuelson, P. (1994): Facets of Balassa-Samuelson Thirty Years Later. Review of International Economics, 2(3): 201-226.

Skidelsky, R. (2017): Stylised Facts. Acta Oeconomica, 67(S2): 31-35.

Summers, L. H. (2015): Demand Side Secular Stagnation. American Economic Review, 105(5): 60-65.

Tica, J. - Druzic, I. (2006): The Harrod-Balassa-Samuelson Effect: A Survey of Empirical Evidence. University of Zagreb Working Paper, No. 06-7/686. 


\section{APPENDIX}

Appendix can be accessed online at: https:/www.mtakti.hu/wp-content/uploads/2020/06/ Complementary.docx.

Open Access. This is an open-access article distributed under the terms of the Creative Commons Attribution 4.0 International License (https://creativecommons.org/licenses/by/4.0), which permits unrestricted use, distribution, and reproduction in any medium, provided the original author and source are credited, a link to the CC License is provided, and changes - if any - are indicated. (SID_1) 